\title{
EL MONO Y EL CACAO: LA BÚSQUEDA DE UN MITO A TRAVÉS \\ DE LOS RELIEVES DEL GRUPO DE LA SERIE INICIAL DE CHICHÉN ITZÁ
}

\author{
Martha Ilia NÁjera Coronado \\ Centro de Estudios Mayas \\ Instituto de Investigaciones Filológicas \\ Universidad Nacional Autónoma de México
}

\begin{abstract}
Resumen: Recientes estudios sobre el cacao han subrayado la relevancia del árbol y de su fruto en diferentes ámbitos de la cultura maya y podría afirmarse que, después del maíz, fue la planta más venerada; su valor destaca en la esfera económica, en la social y, por supuesto, también en la religiosa. A pesar de ello se desconocen mitos sobre cómo los hombres llegaron a obtenerlo; por ello, con base en el modelo mítico mesoamericano del maíz, se propone una interpretación sustentada principalmente en el análisis de algunos de los relieves del Grupo de la Serie Inicial ubicado en Chichén Itzá, en la que el simio juega un papel relevante.
\end{abstract}

Palabras clave: mitología, mono, cacao, Chichén Itzá, cultura maya.

ABSTRACT: Recent studies about cacao symbolism have stressed the importance of this plant and its bean in several contexts of ancient Maya culture, sustaining the assumption that it was the most revered plant after corn. Its value stands out in economic and social terms and, of course, in religious contexts. However, we do not know the mythical beliefs related with its procurement for the human beings; in this paper we propose a possible interpretation, based on the maize mythical model and supported by several representations from the Initial Series Group of Chichén Itzá, where monkeys play an important role.

Key words: Mythical, Monkey, Cacao, Chichén Itzá, Maya culture.

ReCEPCIÓN: 3 de agosto del 2011.

ACEPTACIÓn: 21 de octubre del 2011. 



\title{
EL MONO Y EL CACAO: LA BÚSQUEDA DE UN MITO A TRAVÉS DE LOS RELIEVES DEL GRUPO DE LA SERIE INICIAL DE CHICHÉN ITZÁ*
}

\author{
Martha Ilia Nájera Coronado \\ Centro de Estudios Mayas \\ Instituto de Investigaciones Filológicas \\ Universidad Nacional Autónoma de México
}

A Peter Schmidt y a los miembros del Proyecto Chichén Itzá: 1999-2002 del Centro INAH, Yucatán

\section{Introducción}

El cacao (Theobroma cacao $L$.) fue considerado como un fruto de gran valía en diferentes ámbitos políticos, económicos, sociales y religiosos en la antigua Mesoamérica. Al igual que otras semillas de gran estima para el universo indígena, ha sido objeto de múltiples comentarios y estudios desde diversos ángulos: desde los ofrecidos por los primeros cronistas, frailes y conquistadores, hasta los juicios de europeos que si bien nunca pisaron el suelo americano, se deleitaron con el sabor del chocolate o lo calificaron como un alimento dañino. En los últimos años varios autores han investigado al cacao desde múltiples perspectivas, ya sea epigráficas, lingüísticas, iconográficas, biológicas, etnográficas, por citar algunas, produciendo una literatura muy amplia. ${ }^{1}$

No obstante su relevancia en el mundo prehispánico, poco se ha escrito sobre los mitos de origen del cacao; parecería que no sobrevivieron a la conquista, a diferencia de los mitos fundamentales sobre el maíz que abundan en Mesoamérica y perduran hasta nuestros días. El propósito de este ensayo es, con base en un análisis comparativo con otras creencias e ideas mesoamericanas, rastrear cier-

"Agradezco a Dolores Aramoni, Maricela Ayala, Guillermo Bernal, Michela Craveri, Lynnet Lowe, Tomás Pérez, Rogelio Valencia, Carmen Valverde, María Elena Vega y Francisca Zalaquett los comentarios, sugerencias y apoyo para este artículo, mismo que fue elaborado con apoyo del proyecto PAPIIT IN404909. Asimismo agradezco a Daniel Salazar por haber retocado y redibujado las fotos y dibujos que acompañan este trabajo.

${ }^{1}$ Una de las publicaciones más completas sobre el estudio del cacao entre los mayas es la de Cameron McNeil, (editor) del 2006, titulada Chocolate in Mesoamerica. A Cultural History of Cacao. Reúne diversos artículos, algunos citados en este artículo. La obra contiene una amplia bibliografía. 
tos elementos simbólicos asociados al cacao para tratar de esbozar un antiguo mito que pudo representarse en la antigua Chichén Itzá y donde se incluye a un peculiar personaje: el mono. El artículo forma parte de una investigación mayor sobre la simbólica del pequeño mamífero; una de sus múltiples valencias, según el estudio, se vincula precisamente con el valioso grano. Por ello, solo haré algunas breves referencias al fruto, pues sería imposible en pocas páginas aludir a toda la riqueza de las investigaciones sobre el cacao. Me abocaré a aquellos elementos que permitan comprender los relieves de la Serie Inicial de Chichén Itzá y, por supuesto, sus vínculos con el simio. Por ello, reitero, no se trata de un estudio sobre el cacao.

La producción del árbol del cacao está restringida a ciertas regiones privilegiadas del trópico húmedo. Es propio del bosque tropical perennifolio, biotopo en donde se produce una semilla de buena calidad, como en las regiones del Soconusco (Chiapas y Guatemala) y el norte de Chiapas, así como en las tierras colindantes de Tabasco y Veracruz. Por la escasez de las áreas de cultivo su valor se acrecentó y entonces se empleó como moneda de cambio, se convirtió en uno de los tributos más preciados y en un regalo codiciado por los grandes mandatarios. Al ser elegido por el paladar de la nobleza, se ofrecía durante los grandes acontecimientos sociales como los encuentros entre dignatarios, la celebración de los acuerdos políticos, o al establecerse diferentes tipos de vínculos; también se incluyó en diversas festividades religiosas como las ceremonias matrimoniales, o bien formó parte del ajuar funerario, porque el grano o la bebida acompañarían al dignatario fallecido en su tránsito hacia el mundo subterráneo; además tuvo diversos usos medicinales (Caso y Aliphat, 2008: 68; Andalón González, 2010: $36-40)$. No se descarta que otras variedades de cacao de menor calidad ${ }^{2}$ fueran consumidas por la comunidad.

Entre las diversas bebidas y alimentos que se preparaban con el cacao, fray Diego de Landa destaca que los indios de Yucatán elaboraban un líquido en especial formado con el grano molido y maíz, "una manera de espuma muy sabrosa con que celebran sus fiestas y que sacan del cacao una grasa que parece mantequilla y que de esto y del maíz hacen otra bebida sabrosa y estimada" (Landa, 1994: 115). En textos epigráficos de algunas vasijas también se registra no sólo el uso del cacao, sino también cómo se le acompañaba con maíz, entre otros alimentos que sirvieron para modificar su sabor. Y así como se unieron los dos granos, así también (como se verá) el maíz y el cacao se fusionaron en el ámbito sagrado. Fray Diego Durán cita, en un discurso que le atribuye al gran estadista náhuatl Tlacaelel, que el cacao era sólo para los valientes guerreros mexicas y se consideraba entre las recompensas obtenidas junto con las ropas de algodón, las plumas, las flores, los humazos de olor y las comidas preciadas (Durán, 1967, II, cap. XXXIX: 236). El fraile Bernardino de Sahagún, entre las metáforas que

${ }^{2}$ Theobroma penragonum, "cacao lagarto"; T. leiocarpum, "cacao calabacillo"; y T. bicolor, "patashte" o "pataxte" (Aramoni, comunicación personal 2011). 
enumera, compara el valor de la semilla con elementos altamente valorados del cuerpo humano como pueden ser el corazón y la sangre; escribe:

“Corazón sangre”. Por metáfora se decía de cacao, que solamente le usaban beber los señores y senadores valientes hombres y nobles y generosos; porque valía muy caro y había muy poco. Si alguno de los populares lo bebía, costábale la vida si sin licencia lo bebían, por ésta se llamaba yollotli, yeztli, "precio de sangre y de corazón” (Sahagún, 1989, libro sexto, cap. XLIII: 463).

De hecho el cacao de alta calidad se instaura durante el periodo prehispánico como un distintivo de la élite y como una muestra de prosperidad (Reents-Budet, 2006: 201-223; Andalón González, 2010: 94-102); por otro lado, los glifos de diversas vasijas suntuarias mayas señalan que se preparaba el cacao precisamente para beber (K8713, K6436, K7224), o bien existen escenas donde aparecen los grandes dignatarios bebiendo el preciado líquido. Todo esto podría sugerir que su uso fue en su mayor parte ceremonial.

Pero no sólo los hombres gustaban de su sabor; los dioses también se deleitaban con el grano y formó parte de sus ofrendas. Por ejemplo, en la página 25a del Códice Dresde, ${ }^{3}$ donde la carga del año fue K'awiil (figura 1), se expresa que durante las ceremonias de los días wayeb se ofrecía cacao a la deidad; parte de la inscripción se ha transcrito según algunos autores como kakaw u hanal, "cacao es su alimento", es decir, el alimento del dios. ${ }^{4} \mathrm{O}$ bien los dioses mismos portan un recipiente con mazorcas de cacao como si fuera una ofrenda en diversas escenas del mismo códice. ${ }^{5} \mathrm{Si}$ a esto agregamos que al mezclar el cacao con achiote (Bixa Orellana) se preparaba una bebida que se equiparaba con la sangre humana por el color y la textura, su valor simbólico se acrecentaría como bebida para los dioses (McNeil, 2006: 15).

El cacao, señala Mercedes de la Garza (2012: 200-203), durante los rituales puede mezclarse con hongos, semillas y flores psicoactivas produciendo diversos estados de conciencia; aún sin combinarse es una sustancia estimulante porque contiene teobromina. No resulta extraño que Durán (1967: tomo I, cap. VI, 63-64) cite, refiriéndose al centro de México, que cuando se iba a sacrificar a un representante vivo de Quetzalcóatl como patrono de los mercaderes cholultecas, si se entristecía y ya no deseaba bailar le daban a beber una jícara de cacao en donde se habían lavado cuchillos con sangre humana de sacrificios pasados; con esto, agrega, quedaba sin "ninguna memoria de lo que le habían dicho y casi insensible, y que luego volvía al ordinario contento y baile, olvidado del apercibimiento

\footnotetext{
${ }^{3}$ Es interesante que esta página se vincula con el sur, región del inframundo; y, como se verá, el cacao se asocia con este ámbito (Maricela Ayala, comunicación personal).

${ }^{4}$ Otros autores, como Rogelio Valencia (2010), sugieren que la transcripción sería kakaw u pa'.

${ }^{5}$ Como ejemplos puede citarse en el Códice Dresde la página $10 \mathrm{~b}$ en la que Chaahk porta los granos de cacao y en la 12a el dios del maíz porta las mazorcas y K'awiil los granos de cacao, en la lectura de los glifos se anuncia abundancia de alimento, abundancia de comida.
} 


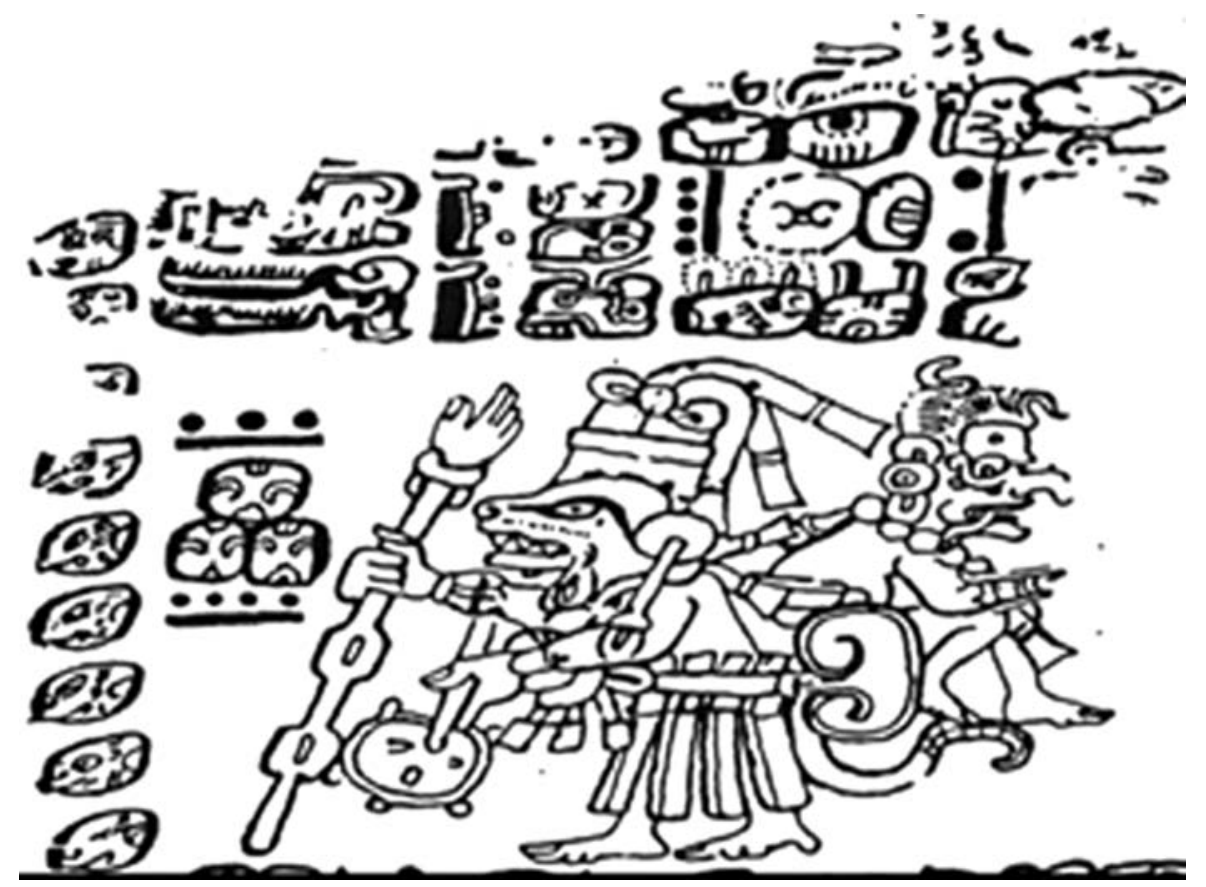

Figura 1. Códice Dresde 25a (Villacorta, 1976)

que le habían hecho”. Aunque el fraile no lo mencione, por la reacción de la víctima podría inferirse que alguna sustancia más sería agregada a la jícara.

Sahagún (1989, libro onceavo, cap. VI: 744) escribe que cuando el cacao es nuevo, si se bebe mucho emborracha; en tanto, si se bebe templadamente, refrigera y refresca. Fuentes y Guzmán (1932: vol. 2, 97), al apuntar sobre las virtudes del cacao en Guatemala, añade que cuando "sale del fruto exuda un líquido excelentísimo y muy fresco, que los indios toman con gran destreza”; no obstante, se fermenta con facilidad y se convierte en una bebida alcohólica (Coe y Coe, 1999: 84). De acuerdo con el texto de Bernal Díaz del Castillo (1991, cap. XCI: 250), incluso se consideró como bebida que potencializaba la sexualidad; relata cómo durante una gran banquete ofrecido por Moctezuma, le llevaban grandes cantidades de cacao espumoso "que decían era para tener acceso con mujeres". El cacao contiene feniletilamina, ${ }^{6}$ una sustancia química que se dice altera la conducta y es liberada en el cerebro cuando una persona se encuentra enamorada (Coe y Coe, 1999: 346).

${ }^{6}$ La feniletilamina es una amina aromática muy simple; es además alcaloide, neurotransmisor, estimulante y antidepresivo. 


\section{El maíz y el cacao}

Como señalé, las historias sagradas sobre el origen del cacao son casi inexistentes; por ello primero mostraré la fusión simbólica entre el cacao y el maíz y luego, a través de un modelo sobre los mitos del maíz mesoamericano, trataré de esbozar uno similar para el cacao. Considero que los diversos pueblos que habitaron la región cultural de Mesoamérica compartieron un sustrato mítico común que se inicia desde periodos tempranos, y si bien se modificó a través del tiempo algunos elementos fundamentales permanecieron por siglos. Entre los nahuas, el único elemento mítico que obtuve sobre el cacao proviene de los Anales de Cuauhtitlan (1992: párrafo 37: 8), obra donde se asegura que Quetzalcóatl en su tiempo descubrió, junto con otras riquezas, el cacao de varios colores; no obstante, no relata cómo llegó a manos del hombre, si bien resulta interesante saber cómo, al igual que el maíz, el cacao puede ser de diversos colores (tal vez cada uno de estos con un simbolismo determinado). En otro texto, Sahagún (1989: libro tercero, cap. III y XII) refiere que Quetzalcóatl en Tula tenía todas las riquezas del mundo, todo lo necesario para comer y beber; poseía: “oro, y plata, y piedras verdes [...] y mucha abundancia de árboles de cacao de diversos colores, que se llaman xochicacaoatl", cuando fue objeto de los engaños de Tezcatlipoca y tuvo que abandonar su ciudad. Primero quemó sus casas, enterró sus riquezas y "convirtió a los árboles de cacao, en otros árboles, que se llaman mizquitl”, dejando sólo miseria.

Entre los grupos mayas, de acuerdo con ciertas representaciones del periodo Clásico, algunas de las historias sagradas del maíz se unen a las del cacao. Simon Martin (2006: 154-156) analiza un cuenco de piedra esgrafiado del Clásico Temprano (250-600 d.C.) para beber cacao que procede de Yucatán, resguardado en la Colección Dumbarton Oaks ${ }^{7}$ (figura 2); sugiere que el cacao fue el primer alimento que creció del cuerpo del dios del maíz, el dador de todas las plantas útiles, por lo cual el árbol del cacao posee una posición privilegiada y sendas semillas pudieron compartir sus mitos. En las dos escenas conservadas aparece un joven al que identifica con el dios del maíz: de sus brazos y piernas crecen vainas de cacao y la piel tiene marcas con motivos de madera. Por ello el autor considera que personifica al dios del maíz, en su aspecto no sólo de dios del cacao sino como encarnación del árbol mismo. Martin se apoya en la lectura de los glifos ixim / ixi'im, que significa "maíz" en casi todas las lenguas mayas, y del glifo te' para "árbol”, por lo cual propone la lectura iximte', "Maíz Dios Árbol” o "Maíz árbol". ${ }^{8}$ También considera que el ciclo del maíz era la metáfora central de la vida y la muerte para los mayas, y el núcleo alrededor del cual se conformaba gran parte de su religiosidad; no deja de ser interesante que ixim se llega a emplear para todo tipo de grano.

\footnotetext{
${ }^{7}$ Dumbarton Oaks Research Library and Collections, Washington D. C. (PC.B. 208).

${ }^{8}$ Si bien ixim significa "grano", en palabras compuestas puede significar toda la planta. Diccionario Maya Cordemex, 1980: 275.
} 

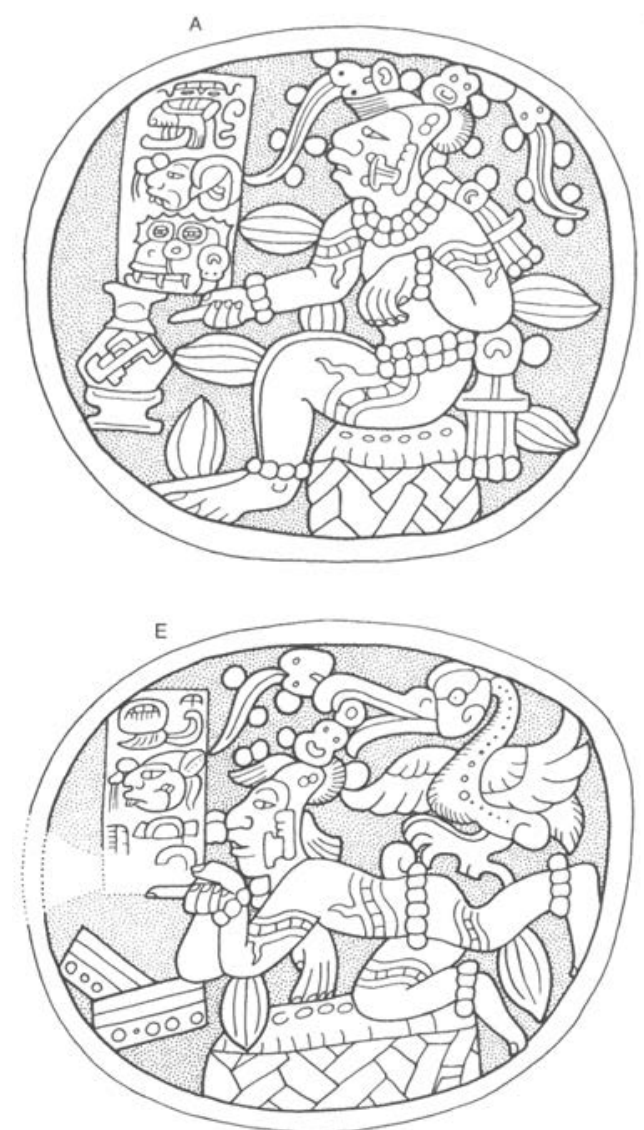

Figura 2. Vasija de la colección de Dumbarton Oaks, Washington. Dibujo de Simon Martin con base en el de Felipe Dávalos y en la fotografía de Justin Kerr 4331 (Martin, 2006, figura 8.1)

Por otro lado, según Mercedes de la Garza (2012: 200-203), las imágenes representan un ritual iniciático de un gobernante ataviado con las características del dios del maíz. En la primera escena el dignatario señala el vaso de cacao y mantiene el ojo semicerrado; en la segunda ya ha bebido el cacao y está tendido boca abajo flotando en las aguas del inframundo. El ojo, señala la autora, lo mantiene muy abierto en una expresión de éxtasis por haber logrado la "visión"; entonces, el contenido del vaso sería de cacao compuesto con alguna flor que le produjo el estado alterado de conciencia. Para los fines de este artículo me interesa destacar, no obstante la diferencia entre las interpretaciones de los dos autores, el vínculo tan estrecho entre el maíz y el cacao, subrayando que del cuerpo del personaje ataviado como el dios del maíz surgen las mazorcas de cacao. 
Martin (2006: 154-156) asimismo analiza el Vaso Trípode del Museo Etnológico de Berlín K6547 (Fig. 3 a y b), fechado en el Clásico temprano. Proviene de la región del Petén Central y, de acuerdo con la inscripción, fue utilizado para beber cacao. En la imagen se relata un ritual funerario con la subsiguiente transformación de la materia inerte para generar nueva vida. En un primer momento, el cuerpo amortajado y ataviado con algunas de las características de la deidad del maíz se ubica bajo una montaña marcada con el grano de la mazorca del maíz, llamado por algunos estudiosos la Montaña de la Flor y que cabría identificarlo con el Tonacatepetl del centro de México o la Montaña de Nuestro Sustento o la Montaña de los Mantenimientos. En la segunda escena el cuerpo, ya esquelético, yace bajo una pirámide escalonada, otra imagen de una montaña sagrada; sobresalen tres personajes en posición descendente, cuyo cuerpo se transforma en tres tipos de árbol. El del centro, el que corresponde al renacimiento y transfiguración de nuestro protagonista, es precisamente el árbol del cacao, sobre el cual un ave nocturna caza una serpiente. Su resurrección en forma de una planta tan preciada es una forma de permanecer y de ayudar al pueblo del que fue gobernante. Los otros podrían ser sus padres, como sucede en el sarcófago de Palenque en donde el cacao le corresponde a la madre del gobernante, la Ix Sak' K'uk', "Señora Quetzal Resplandeciente" (McNeil, Hurst, Sharer, 2006: 250). ${ }^{9}$ Por lo tanto, el gobernante fallecido, quien primero se identifica con el maíz,

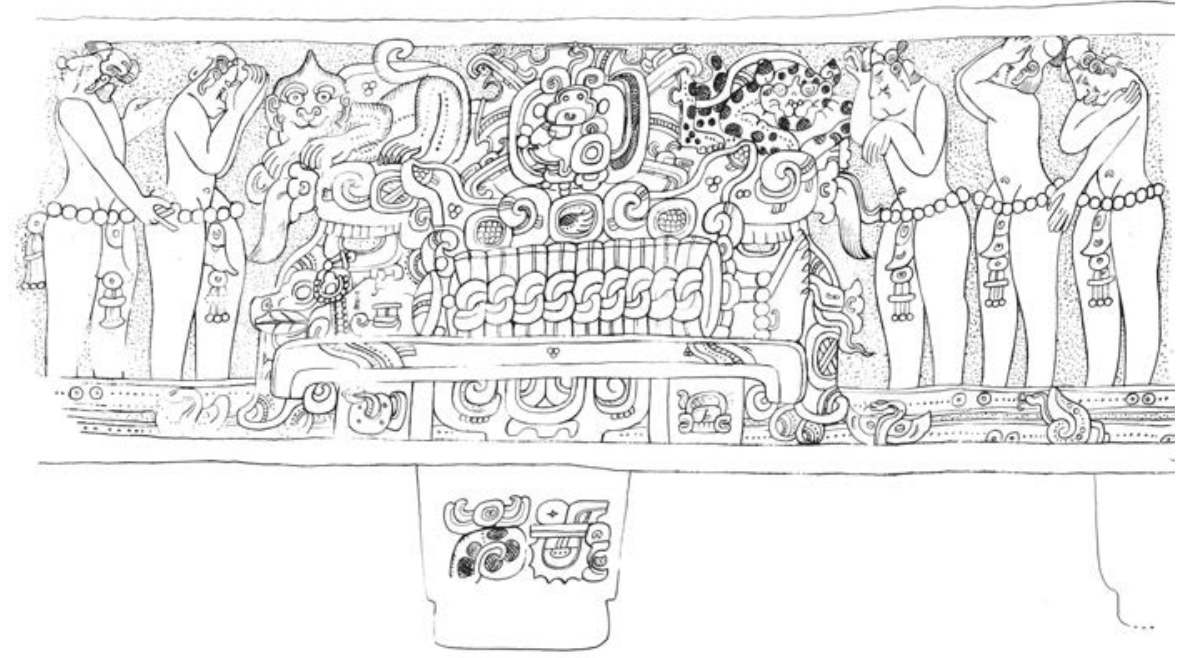

Figura 3a. Vaso Trípode de Berlin K6547. Región central del Petén. Dibujo de Lothrop, figura 25

\footnotetext{
${ }^{9}$ Según McNeil, Hurst y Sharer (2006: 250) las representaciones de ancestros como árboles de cacao aumentan durante el periodo Clásico Tardío, particularmente en Copán. Esto podría responder al interés de los gobernantes por incrementar la producción de cacao durante este periodo.
} 


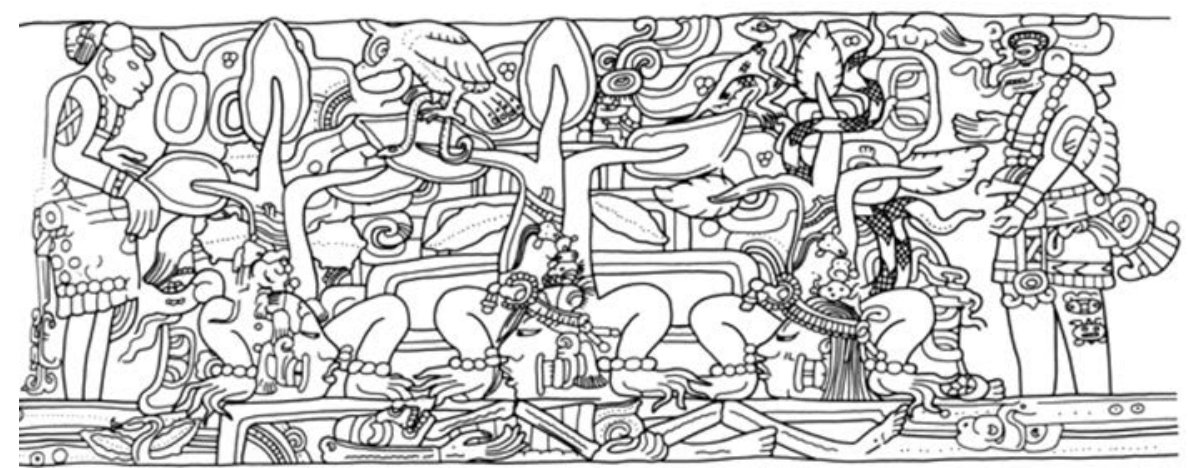

Figura 3b. Vaso Trípode de Berlin K6547. Región central del Petén.

Dibujo de Grube (2006: figura 12.13)

se entierra en la Montaña de los Mantenimientos y es de aquí de donde surge transfigurado como el árbol sagrado del cacao, quizá reactualizando con su florecimiento un mito que trata sobre el lugar de origen de este grano. La montaña es, en las concepciones de lo nahuas, un gran recipiente en donde también se hallan las "semillas-corazones", las sustancias divinas de los individuos muertos que esperan, bajo la tierra, la oportunidad de volver a surgir a la superficie (López Austin, 1994: 183-185).

La estrecha relación entre la deidad del maíz y el cacao se mantiene durante el Clásico Tardío, como se muestra en un incensario probablemente de Río Bec. En él se observa cómo el joven dios, en posición descendente, porta en sus manos una mazorca de cacao y se erige como el dador de todas las frutas útiles (Martin, 2006: 167) (figura 4). Asimismo, en un vaso cilíndrico de las Tierras Bajas del norte de Guatemala, Chinchilla Mazariegos (2005: 112, figura 9) ha leído la frase yuk'ib ta iximteey(?) kakaw, y propone que puede referirse a una bebida de cacao relacionada con el dios del maíz o bien a una bebida elaborada con sendos granos (figura 5). Esta complementaridad del maíz-cacao se reafirma en los rituales contemporáneos donde se ofrendan, a las cuatro direcciones, tamales hechos de masa de maíz y cacao en ocasión de la siembra y como petición de fertilidad (Craveri, 2011, comunicación personal).

En un periodo histórico más tardío, el mito k’iche' del Popol Vuh incluso indica que el cacao (Theobroma cacao) se encontraba, junto con las mazorcas de maíz blanco y amarillo, a un lado del pataxte (Theobroma bicolor), ${ }^{10}$ los zapotes, las anonas, los nances y los jocotes, alimentos resguardados en Paxil, ${ }^{11}$ la "montaña

${ }^{10} \mathrm{Al}$ pataxte en maya yucateco se le conoce como balamte', “'árbol del jaguar”.

${ }^{11}$ En k’iche', según Craveri (2011) significa "montaña hendida”. De acuerdo con Carlos Navarrete (2002: 19-22) Paxil en mam significa "agua que corre debajo"; es un punto referencial, una potencia sagrada y un cerro en el municipio de La Libertad, departamento de Huehuetenango, en los Altos Cuchumatanes. 

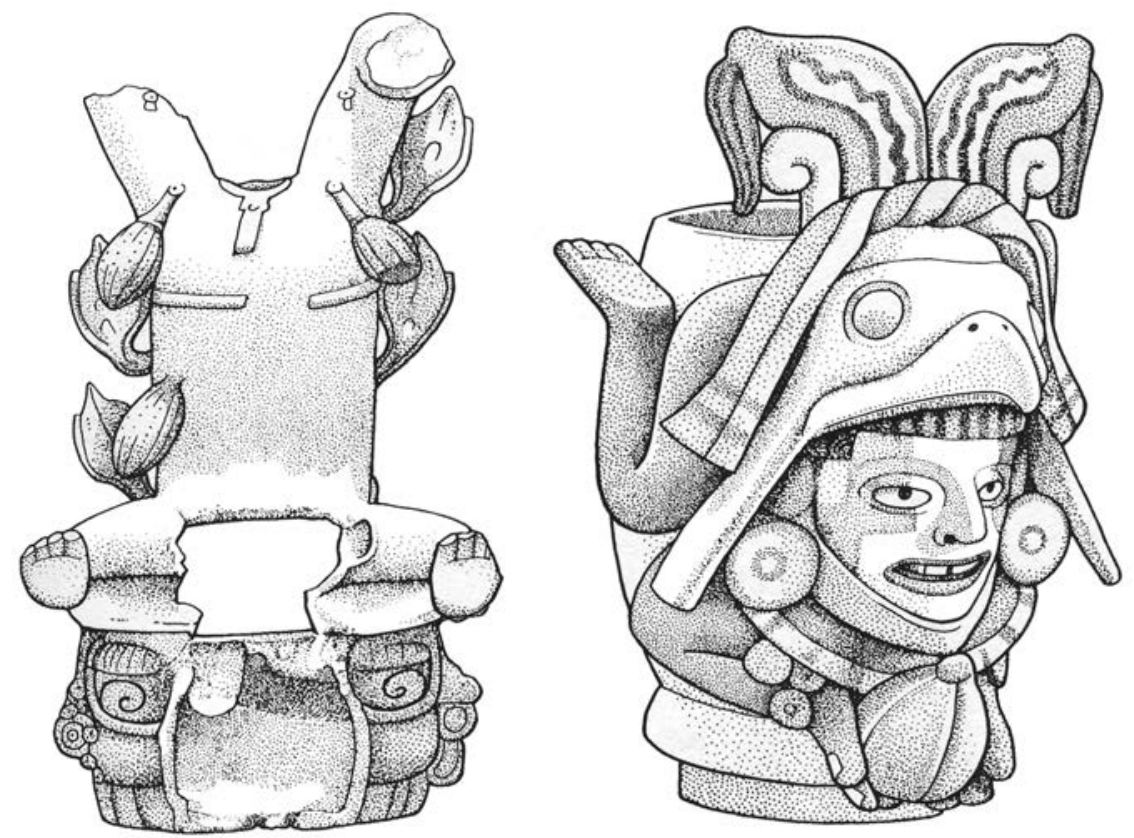

Figura 4. Incensario, posiblemente de Río Bec. Periodo Clásico tardío. (Dibujo de Simon Martin con base en una fotografía de Peter Schmidt. Martin, 2006, figura 8.9)

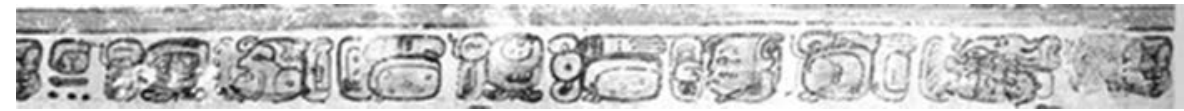

Figura 5. Fragmento de un vaso para bebida de cacao. Periodo Clásico (Chinchilla, 2005: figura 9)

hendida", el lugar de los mantenimientos; aunque no se vuelve a hablar del cacao como tal ni cómo llegó al hombre, más adelante el texto sólo cita a una deidad femenina: Ix Kakaw. Es interesante que no todos los frutos citados son propios del área k'iche', sino de zonas tropicales, de las llanuras costeras de Guatemala y Chiapas, o bien del área de Tabasco, adecuados para el cultivo de cacao, y que sería el paisaje propio que en el imaginario se tendría del interior de la gran Montaña de los Mantenimientos.

Si bien el maíz y el cacao se integran en una deidad, a la vez expresan una dualidad: el maíz pertenece al ámbito solar, a los espacios abiertos, a lo masculino, necesita de la luz para su cultivo, crece hacia arriba, es un alimento caliente; en contraste, el cacao necesita cultivarse bajo la sombra protectora de árboles más grandes para su desarrollo, evoluciona bajo circunstancias de dosel cerrado, su fruto se despliega hacia abajo, sus flores comienzan a abrirse gradualmente 
por la tarde, continúan por la noche y abren completamente justo antes del amanecer y (a diferencia del maíz) se considera un alimento frío. Por ello el tejido simbólico del cacao se vincula con la oscuridad, la noche, las cuevas, la mitad húmeda del año, lo negro, las nubes, los lugares fríos y húmedos y por ende con lo femenino y la Luna (Kufer y Heinrich, 2006: 401). No es fortuito que en el dintel 3 de Piedras Negras, en donde se representa un encuentro del gobernante 4 en el aniversario del primer katun de su regencia con un grupo de nobles, la bebida elegida sea tikal cacaw, "cacao calentado" o bien "fermentado", ${ }^{12}$ y se saborea precisamente durante "el crepúsculo, al atardecer”, en la parte fría del día y cuando empieza a aparecer la oscuridad (María Elena Vega, comunicación personal, 2011). Por otro lado la semilla, de acuerdo con Faust (1998: 603-642), pudo haber sido considerada como símbolo de los genitales femeninos porque el pliegue longitudinal de ésta se asemeja a una vulva.

El cacao, además de ser un elemento frío, al ser terrestre se concibe como un alimento pesado. Ya Durán relataba en el siglo xvı, con referencia al centro de México, que cuando Moctezuma quiso saber cómo era su lugar de origen, las Siete Cuevas, y mandar un presente a la madre de su dios protector Huitzilopochtli, envió a un grupo de ancianos naguales al cerro Colhuacán quienes, entre los presentes, llevaban cacao; los emisarios se encontraron con un hombre de edad avanzada que les ofreció guiarlos ante la diosa madre, pero el suelo era muy arenoso y los enviados de Moctezuma se sumergían hasta la cintura por ser muy pesados. Se les explicó que era principalmente porque bebían cacao y ese alimento los llevaría a la muerte; más adelante la diosa les manifiesta: "Mirad, todo ese daño os ha venido y se os ha causado de ese cacao que bebéis y de esas comidas que coméis; ésas os han estragado y corrompido y vuelto en otra naturaleza”. El cacao, según Coatlicue, era un alimento pesado y corrupto (contrario a la vida pobre y llana que permitía conservar una larga existencia), y les impedía llegar a su lugar de origen (Durán, 1967, II, cap. XXVII: 215-222).

\section{Los relieves de Chichén Itzá}

Como señalé en un principio, algunas representaciones localizadas en Chichén Itzá del Clásico Tardío y Posclásico Temprano, ubicadas principalmente en el Grupo de la Serie Inicial, y otras procedentes de El Osario, ${ }^{13}$ podrían coadyuvar a

12 El hecho de que se refieran al "cacao calentado" o "fermentado", no implica que entre los mayas se considerara un elemento "frío", dado que las categorías "caliente" y "frío" no están relacionadas con la temperatura de los alimentos.

${ }^{13}$ Sendos grupos arqueológicos fueron estudiadas durante el proyecto dirigido por Paul Schmidt (1999-2002). El de la Serie Inicial se construyó sobre una gran plataforma, situado dentro de lo que se conoce tradicionalmente como Chichén Viejo; se localiza en el extremo sur (oeste) del centro arqueológico, a $800 \mathrm{~m}$ al sur del Grupo de las Monjas en la parte central de Chichen Itzá. Se han reconocido dos fases: la primera se ubica entre el Clásico tardío y terminal temprano (600 a 850 
conformar un mito alrededor del cacao. En estas imágenes se reafirma el vínculo simbólico de las semillas y el fruto con las fuerzas nocturnas e ilustran cómo el cacao tuvo su origen en el interior del lugar de los mantenimientos.

En Chichén Itzá hay muchos obstáculos naturales para su cultivo, la precipitación pluvial es baja, su suelo se compone de una llanura kárstica caliza, casi no hay ríos y carece de los ricos suelos aluviales favorables a su desarrollo; solo es posible sembrar el cacao en zonas húmedas como las cercanas a los cenotes, con resultados no muy exitosos ${ }^{14}$; además, los cultivos con toda seguridad fueron propiedad de linajes ricos (Coe y Coe, 1999: 79-80). Por ello los itzáes, para erigir su ciudad como un lugar de gran prestigio, debieron intentar recrear a través del imaginario que su ciudad era un lugar siempre próspero, sumamente fértil, de suelos ricos, colmada de bienes en donde abundaban las plumas finas, el jade y desde luego el cacao, símbolo de la opulencia, como un espacio similar al interior de la Montaña de los Mantenimientos. El cacao, entonces, se convierte en un símbolo de las fuerzas preciosas de agua y del crecimiento de las plantas, muestra de poder y de riqueza.

En los relieves de la fachada superior del Grupo del Osario (Schmidt, 2007: 175) las mazorcas de cacao descienden sobre un personaje en posición frontal adornado con gran lujo, un enorme tocado, una máscara de ave y los brazos extendidos a los que se adhieren plumas que surgen de un mascarón de perfil con rasgos estilizados de serpiente. En la mano derecha porta un cetro o quizá una sonaja cuyo mango se transforma en una cabeza de serpiente; en la izquierda porta un pequeño tambor doble. El atavío denota su soberanía e indica el poder divino que los gobernantes tienen sobre la tierra otorgado por Itzamnaaj, uno de los dioses más relevantes del panteón maya, vinculado con la creación y con los poderes celestes; parecería que el gobernante danza para provocar la fertilidad del cacao ${ }^{15}$ (figura 6).

En las imágenes de los tableros de los tres cuerpos superiores ${ }^{16}$ varias mazorcas de cacao caen entre dos aves de perfil que se miran frente a frente; estos seres aparecen barbados, con una larga nariz bifurcada y enormes garras de ave de presa. En el torso llevan el mismo tipo de plumas adheridas al perfil serpentino que el personaje de la fachada del Templo del Osario; las largas plumas también componen el tocado de esta última figura y la cola, además lleva orejeras, diadema y pendiente (Schmidt, 2007: 174). Debe tratarse de Mut Itzamnaaj, manifestación de Itzamnaaj como ave serpiente, la gran deidad creadora celeste,

d.C.) y el Clásico terminal (800-1000 d.C.); la segunda fase se ha fechado en el Posclásico temprano (1000-1250 d. C.). Los tiestos que se han localizado son del Complejo Sotuta y algunos agregados del Complejo Hocaba (850 d. C. a 1150 d. C. y 1150 d. C. a 1250 d. C.) El de El Osario se encuentra al sur poniente de la Gran Plataforma (Schmidt, 1999: 34; 2002 1-5; y 2007: 173).

${ }^{14}$ Sobre todo si se compara con otras zonas mesoamericanas más favorecidas para su cultivo.

${ }^{15}$ Se encuentran dieciséis paneles con estas imágenes.

${ }^{16}$ Schmidt (2007: 174) indica que las tres terrazas superiores llevan dos paneles esculpidos sobre cada lado de la escalera, sumando un total de 48 paneles que muestran las citadas aves mitológicas. 


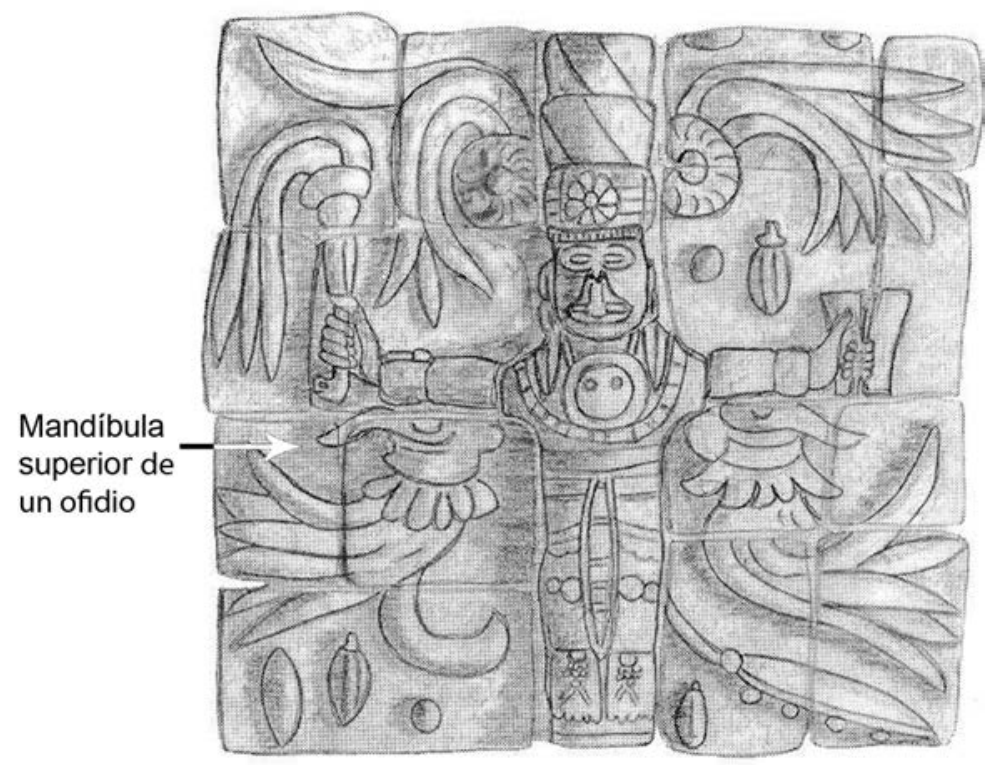

Figura 6. Fachada del Templo del Osario.

Dibujo realizado por Guillermo Couoh Cen y Peter J. Schmidt (Schmidt, 2007, figura 21)

que en este caso puede simbolizar su propio poder solar; no obstante la nariz evoca a K'awiil, deidad ligada con, entre otros aspectos, linajes ilustres, pero también con la regeneración vegetal. Por esto quizá estemos ante la presencia de Itzamnaaj K'awiil (cf. Garza, 1998: 93-96) (figura 7).

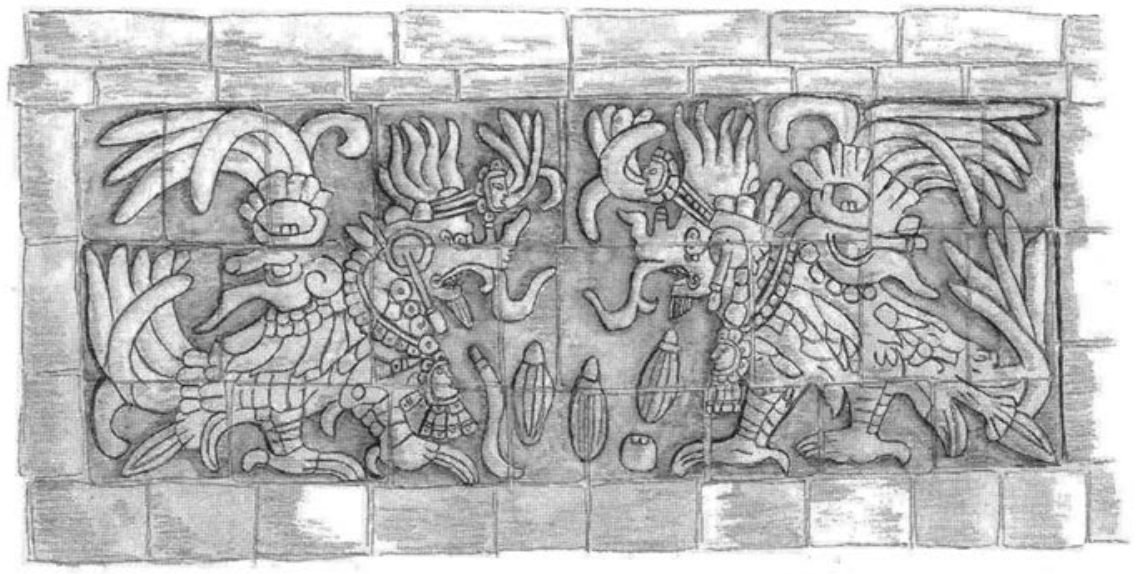

Figura 7. Terraza superior de la Plataforma del Osario. Dibujo realizado por Guillermo Couoh Cen y Peter J. Schmidt (Schmidt, 2007, figura 20) 
En el Grupo de la Serie Inicial de Chichén Itzá (figura 8) es en donde se reitera que el cacao es el preciado fruto resguardado en un sitio paradisiaco similar a la

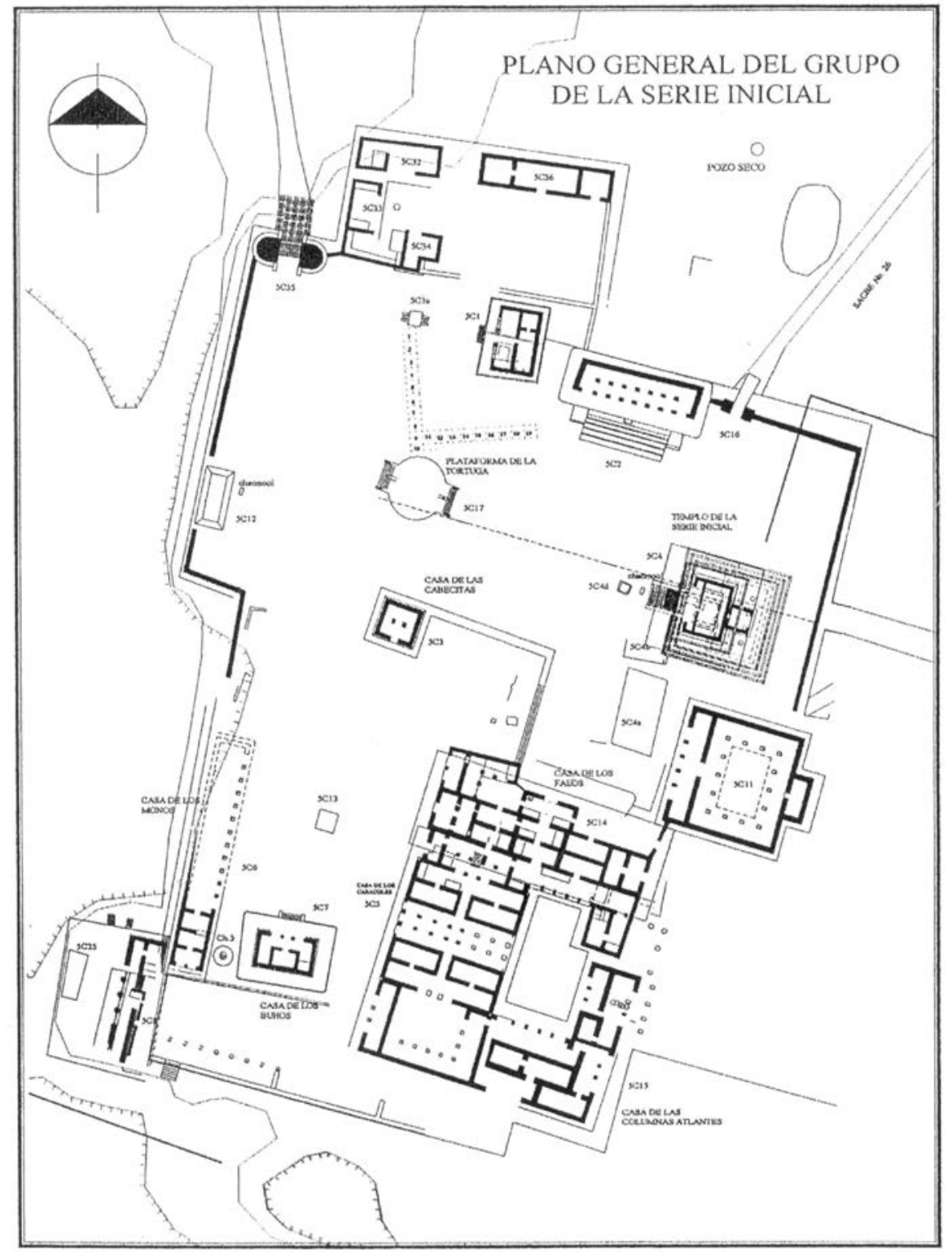

Figura 8. Plano general del Grupo de la Serie Inicial localizada al sur de Chichén Itzá. La plaza cubre una extensión de $44 \mathrm{~m}$ de norte a sur y 27 m este a oeste. Realizado por Francisco Pérez Ruiz (Schmidt, 2007, figura 24) 
Montaña de los Mantenimientos, donde abunda la riqueza y la fertilidad. Si bien los arqueólogos consideran que se trata de un área residencial y administrativa de uno de los linajes de la élite, también tuvo una vocación religiosa que se mantuvo constante en su trayectoria histórica, pues no todas las construcciones son simultáneas (Schmidt, 2003, 2005, 2007).

La entrada más espectacular a este conjunto se realiza por una gran bóveda maya ubicada precisamente hacia el oeste, el rumbo por donde, en el plano simbólico, se penetra al interior de ese espacio inframundano lleno de riquezas; desde ahí al centro de la gran plaza noroeste destaca la enorme Plataforma de la Tortuga (5C17) de forma circular, con la cabeza y la cola esculpidas, así como cuatro extremidades que conforman las alfardas de las escaleras. Este reptil simboliza a la tierra en cuyo interior se encuentran en potencia todas las semillas de las plantas útiles al hombre. No es fortuito que se encontrara un relieve en piedra con la imagen de un conejo en la Luna que dio nombre a una galería (5C11) (Schmidt, 2003, III, figura 20), porque simbólicamente el inframundo y el cielo nocturno se identifican, ambos pertenecen a lo oscuro, lo fértil y lo acuoso.

Las mazorcas de cacao destacan en la decoración de los edificios ubicados hacia el sur del Grupo de la Serie Inicial, región simbólica identificada con el inframundo. ${ }^{17}$ Por ejemplo, en el friso de la fachada norte del edificio inferior de la Casa de los Falos (5C14) la mazorca se labró entre figuras de Pawahtunes, deidades ancianas que surgen de elementos terrestres como caracoles, telarañas, caparazones de tortuga, y que entre sus funciones tenían sostener la superficie terrestre o quizá un cielo oscuro (figura 9). ${ }^{18}$ Durante la época colonial a éstas deidades (junto con las de la lluvia, los Chaahk), se les rendía culto como "dueños de la foresta y cenotes" y se les veneraba en las cuevas y en los cenotes (Chuchiak, 2000: 268-270). En la imagen los dioses danzan mientras se autosacrifican el miembro viril; su sangre cae en una vasija que se advierte entre sus pies. El ritual divino podría vincularse con la fertilización de la valiosa semilla. ${ }^{19}$

Una vez más el cacao es motivo central de una escena que se desarrolla en el cielo nocturno, una letanía en los relieves de los tableros norte y sur de la fachada superior de la Casa de Falos localizada al oriente de la plaza (Schmidt, 2003, III: figuras 31 y 32; Schmidt, 2007, 183). Las mazorcas de cacao descienden como dones divinos, mientras el personaje central de frente, con rasgos faciales de serpiente y jaguar, suntuosamente ataviado, extiende los brazos; a estos se sujetan nuevamente plumas que se adhieren al perfil serpentino. Además sostiene un plato en cada mano con diversos bienes, por lo cual se erige como "aquel que otorga". La figura humana se ubica sobre una franja celeste que descansa sobre el torso de un jaguar en actitud amenazante; una banda de signos de Venus o es-

\footnotetext{
${ }^{17}$ Me refiero a parte de la decoración del Grupo de los Falos, del Palacio de los Caracoles, del Templo de los Búhos y de la Galería de los Monos.

${ }^{18}$ Schmidt contó hasta un total de 14 paneles con Pawahtunes (2003: I, 14)

${ }^{19}$ Schmidt (2007: 183) menciona que existen entre catorce o quince paneles esculpidos con las imágenes de los Pawahtun autosacrificándose que adornan las fachadas superior norte y este.
} 


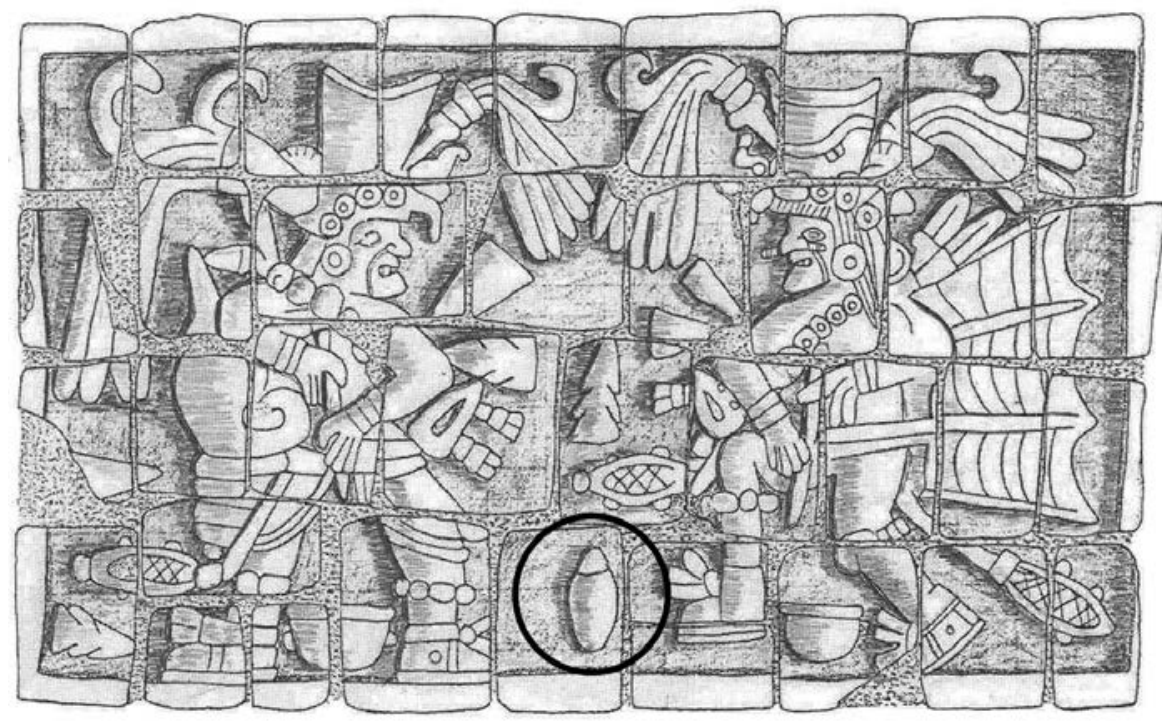

Figura 9. Dibujo del panel 9 de la fachada norte y este inferior, Casa de los Falos (Schmidt, 2003, III: figura 23). Dibujos realizados por Guillermo Couoh Cen y Peter J. Schmidt

trellas delimita la parte inferior de la escena. Por el entorno y los atributos podría tratarse de una deidad, probablemente el Sol nocturno que renace por el oriente: y aparece entre personajes antropomorfos con máscara de aves que danzan y tocan un pequeño tambor de mano, pax, participando en una solemne y bulliciosa ceremonia (que incluye el sonido de cascabeles, movimientos y sonidos rituales que propician la abundancia del cacao) (figuras 10a y 10b). En los relieves de la fachada del piso superior, este y oeste, se representan tres jaguares que a decir de Schmidt, se encuentran en "un baile desenfrenado" (Schmidt, 2003, I: 15); el simbolismo de estos animales reitera el ámbito nocturno al que nos hemos referido.

En los frisos de las fachadas este y oeste de la Casa de los Falos superior, así como en los de la fachada oeste de la Casa de los Caracoles (5C5), las mazorcas de cacao retoñan entre hojas, flores y aves a través de un brote que surge del falo de personajes con máscaras de ave, barra nasal, plumajes en los brazos y tocados elaborados (figura 11). Cada hombre-pájaro ${ }^{20}$ nace de una enorme semilla y sostiene la planta; de cada tallo surgen en abundancia enormes mazorcas de cacao, así como hojas y flores en donde se posan aves que liban en los cálices. Schmidt (2003, I: 18) sugiere que el relieve de donde eclosiona la deidad puede tratarse de una jícama de monte kup $;^{21}$ no obstante, me inclinaría por interpre-

\footnotetext{
${ }^{20}$ Son tres personajes; sólo dos llevan máscara con pico de ave (Schmidt, 2003: I, 17-18).

${ }^{21}$ Schmidt (2003: I, 18) sugiere que este edificio debió tener la función de una Casa del Linaje, y que podría tratarse de los "Cupules", dueños de la región de Chichén Itzá al momento de la conquista española, lo cual se indicaría con la kup o cup.
} 


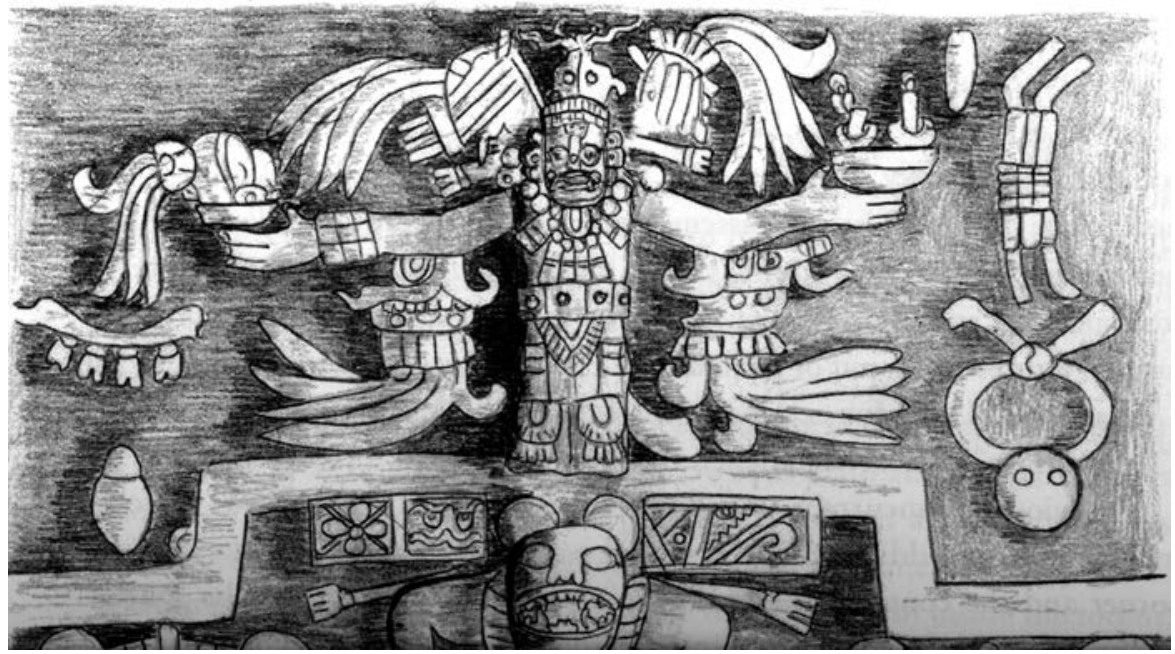

Figura 10a. Dibujo del relieve de los paneles norte y sur de la Casa de los Falos de la fachada superior (Schmidt, 2007: figura 27c). Dibujos realizados por Guillermo Couoh Cen y Peter J. Schmidt

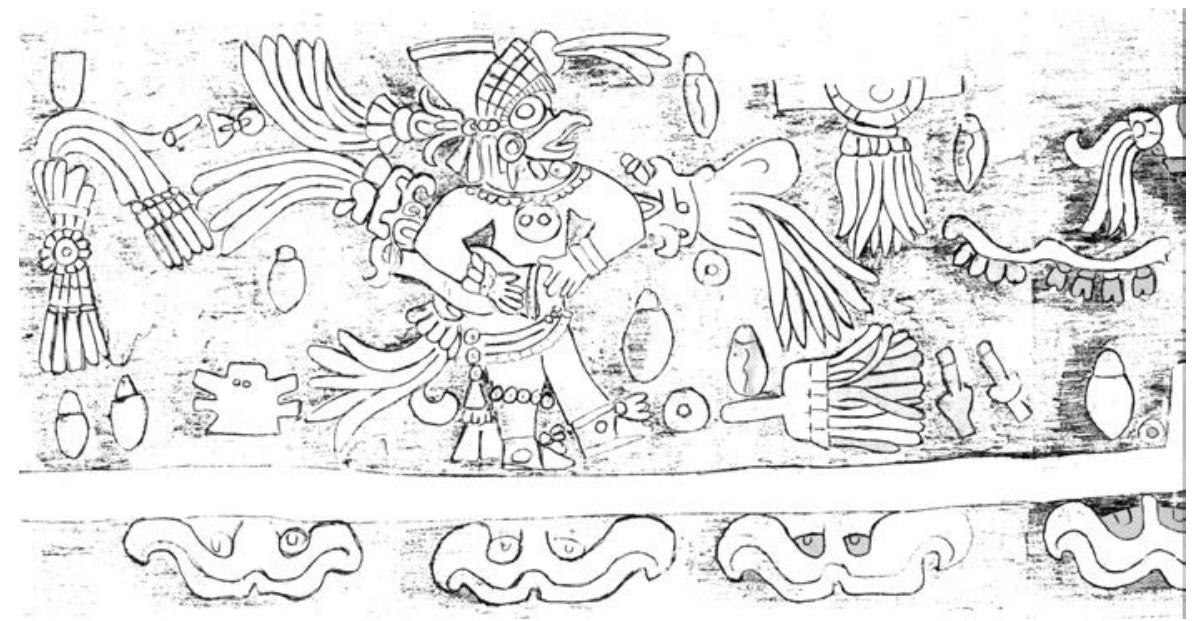

Figura 10b. Dibujo del relieve de los paneles norte y sur de la Casa de los Falos de la fachada superior (Schmidt, 2003, III: figura 31a). Dibujos realizados por Guillermo Couoh Cen y Peter J. Schmidt 


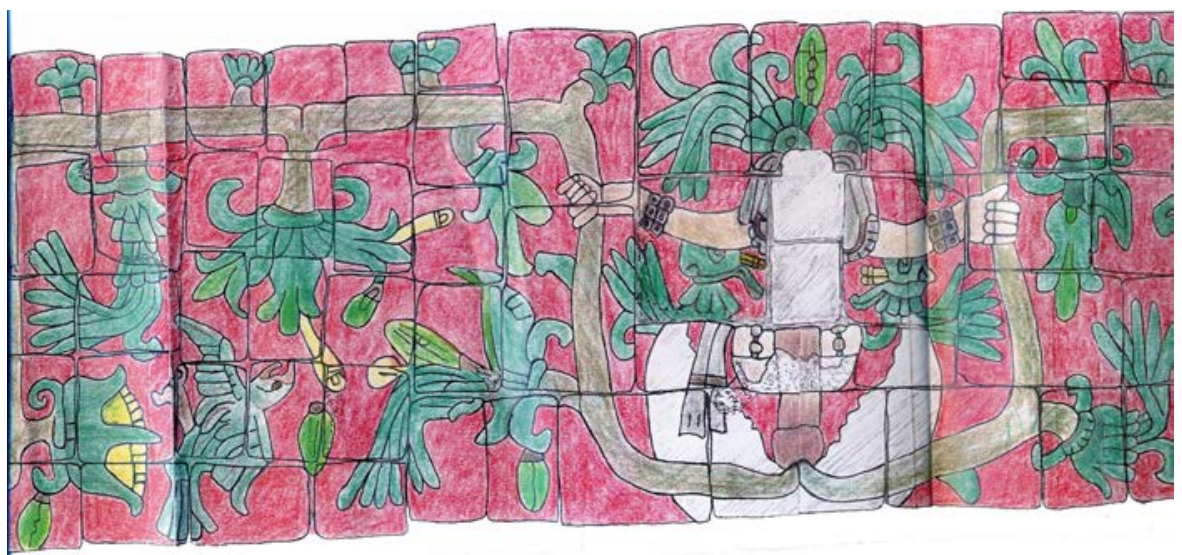

Figura 11. Dibujo del friso de la fachada oeste de la Casa de los Caracoles. Personaje central. (Schmidt, 2003, III: figura 36. Dibujos realizados por Guillermo Couoh Cen y Peter J. Schmidt)

tarlo como una representación simbólica más del sitio de los mantenimientos, espacio donde se guardan todas las semillas y que se hiende para dar lugar al nacimiento de las plantas útiles al hombre, en este caso en alusión especial al cacao. Los pequeños caracoles que le dan nombre al edificio y que adornan una de las molduras nos remiten también a un simbolismo de origen; además esta estructura está orientada hacia el este, lugar del nacimiento por antonomasia. Pérez Ruiz et al. (2009: 301-302) lo consideran como un paraíso mítico, en donde se observa como el personaje principal surge y otorga vida exuberante, las aves fecundan las flores, todo un acontecimiento mítico ligado con la creación.

El culto al cacao, la recreación del ámbito nocturno y terrestre se reitera en la Casa de los Búhos (5C7), en donde predominan en la decoración las imágenes de aves noctámbulas y una hilera de pequeñas tortugas sobrepuestas a una moldura media. La estructura se sitúa hacia el sur del Grupo de la Serie Inicial, región que de hecho pertenece al mítico inframundo, y su fachada da para el norte. El cacao figura en la tapa 2 de la bóveda: varias vainas maduras crecen tanto de una banda celeste como dentro del propio inframundo y enmarcan a un K'awiil alado, deidad vinculada con la abundancia, la fertilidad y el linaje. La deidad emerge de las fauces de una gran serpiente del inframundo, portando una vasija con cuentas esféricas coronadas por orejeras de jade (figura 12). ${ }^{22} \mathrm{~K}$ 'awiil, señala Martin, en muchas ocasiones porta granos de maíz; además, por sus atributos a veces sus actividades se traslapan con las del dios del maíz y las de Chaahk en su función del dios del rayo (Martin, 2006: 170-175). La lectura que realiza

22 Otro ejemplo en el que K’awiil porta granos de cacao es la tapa de bóveda de "Ciudad de México" (Museo Amparo). 
Guillermo Bernal (2011, comunicación personal) de los glifos que figuran en la parte superior completa la idea:

a-la-yo 1-AJAW 10-?-? 13-?-? no?-u K'AHK'-TUUN U-yi?-IL-? WINIK-AJAW-2ma-li b'a K'AWIIL ka-ka

ala'ay ju'n ajaw laju'n-? uxlaju'n-? no[h?] u' K'ahk' tuun u yi-il?_, winik ajaw mamil b'a[ah] K'awiil kaka[w]

aquí, en el día 1 Ajaw, 10_ 13_ , ¿la Gran Luna?, la Piedra de Fuego, los Antepasados/Abuelos del Hombre Gobernante vieron la imagen del dios K'awiil del Cacao (o del cacao del dios K'awiil) ${ }^{23}$

Si bien resultan enigmáticos algunos elementos del texto, se reitera cómo en una fecha que recrea un acontecimiento mítico los ancestros de un gran gobernante de los itzáes fueron testigos de que K'awiil portaba el cacao. Por ello, se puede inferir que en la escena de la citada bóveda de Chichén Itzá K’awiil rescata del inframundo las semillas representadas como joyas preciosas.

Un pasaje mítico similar se relata en el texto colonial yucateco del Libro de Chilam Balam de Chumayel; se expresa que después de una de las destrucciones del mundo, Yax Bolon Dzacab, el "Gran nueve fecundador" (forma colonial de K'awiil), recoge "habas molidas junto con su semen, y junto con su corazón, semilla molida de calabaza, y semilla gruesa molida de calabaza, y frijoles molidos... y lo envolvió y lo ató todo junto, y se fue al decimotercer piso del cielo" ("Libro de los antiguos dioses", 1985: 88). Conforme con lo representado en la tapa de bóveda se podría suponer la existencia de algún mito similar que relatara cómo junto a estas semillas la deidad también resguardó el cacao y con posterioridad lo donó a la humanidad.

Siguiendo los textos míticos coloniales, al restaurarse el cosmos se colocan cinco ceibas como pilares que evitarían que el cielo y la tierra volvieran a unirse y se regresara una vez más al caos. Quizá en Chichén Itzá se creyó que alguno de estos árboles podría ser un árbol de cacao, pues en la misma Casa de los Búhos se labraron en pilares policromos árboles de cacao cargados de frutos, flores y quizá jades (figura 13). En la construcción original, de acuerdo con el arqueólogo Schmidt (2007:189), del orificio de la base surgía un personaje con los brazos cruzados, que evoca algunas imágenes del dios del maíz con frutos de cacao; así, las historias sagradas de sendos granos vuelven a unirse. Estos árboles recuerdan al del cacao que ocupa el rumbo sur del Códice Féjérvary Mayer o Tonalámatl de los Pochtecas (lámina 1) de la tradición mixteca-poblana. El árbol surge de las fauces del monstruo de la tierra y es flanqueado por Mictlantecuhtli y Cintéotl, deidades de la muerte y del maíz respectivamente, por lo que reúne las mismas valencias que en el área maya; el loro que corona al árbol es también propio de las regiones en donde se cultiva el cacao. Otro árbol similar que simboliza un axis

${ }^{23}$ Agradezco a Guillermo Bernal la traducción del texto de la tapa de bóveda. 


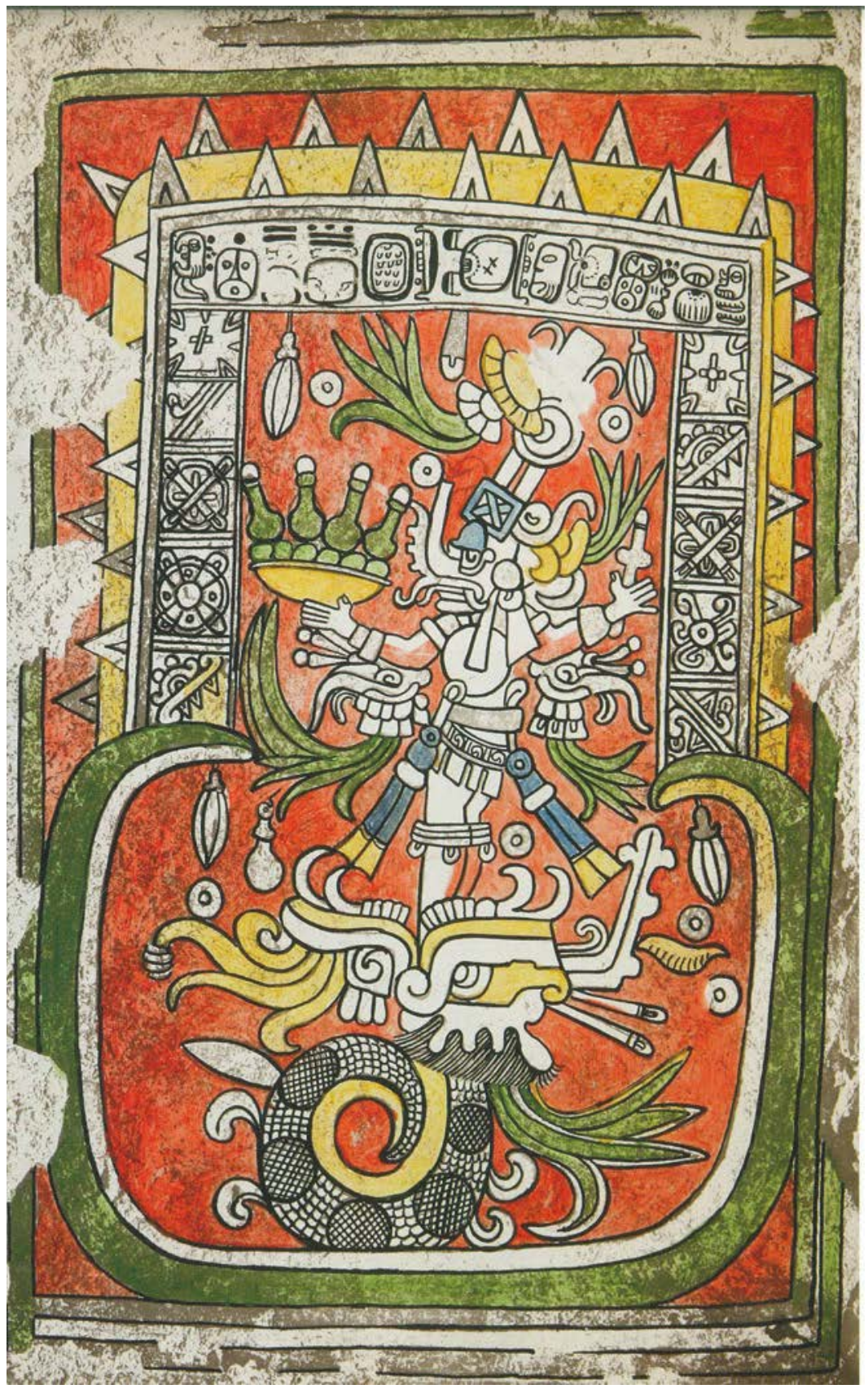

Figura 12. Tapa de bóveda de la Casa de los Búhos (Dreiss y Edgar Greenhill, 2008: figura 2.2). Fotografía coloreada por T. A. Willard, 1920. Autry National Center, Southwest Museum, Los Ángeles, Photo no. N43284 


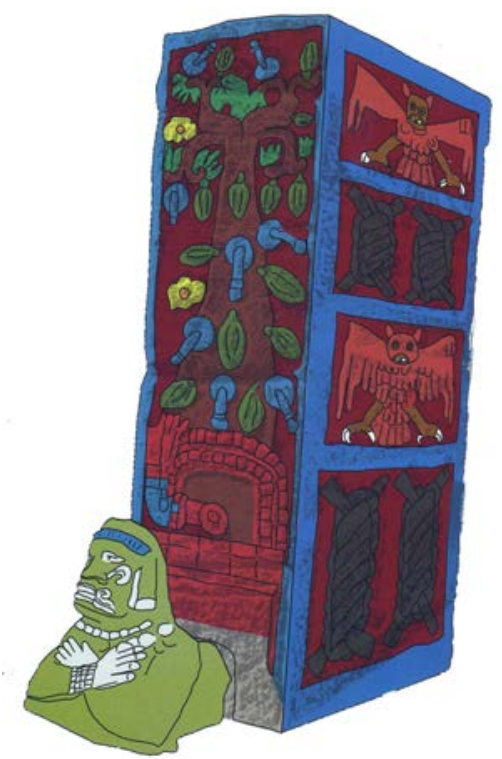

Figura 13. Árbol de cacao procedente de la Casa de los Búhos (Schmidt, 2007: 189)

mundi se localiza en un incensario de piedra de la Acrópolis de Copán, Honduras, representado como el cuerpo de un cocodrilo invertido con vainas en el cuerpo (McNeil, Hurst y Sharer, 2006: 245; Martin; 2006).

Y en el ya citado conjunto de El Osario, en Chichén Itzá, se descubrió la imagen de un árbol de cacao que conforma el cuerpo erguido de un gran saurio, en un relieve que procede de la Estructura 3C6 (figura 14); siguiendo a Schmidt, el relieve fue reutilizado y debió proceder precisamente del Conjunto de la Serie Inicial. Al surgir del cocodrilo la planta de cacao, esta se erige simbólicamente como un árbol de origen colocado en un eje cósmico. En el fragmento de Chichén Itzá, se alcanza a ver la extremidad inferior de un mono que se acerca, personaje al que a continuación me voy a referir.

\section{El mono y el cacao}

El mono araña se representa junto con el cacao en múltiples representaciones mesoamericanas, lo que refleja la mutua dependencia que existe entre sendos organismos en la naturaleza. La mazorca del cacao permanece en el árbol al madurar y está sujeta a los animales arbóreos para dispersar su semilla; al mismo tiempo, al mono le atrae la pulpa dulce y sabrosa del cacao. El simio es un dispersor consuetudinario de las semillas, ya sea porque consume la pulpa con el grano intacto y al defecar las distribuye, o bien porque al acarrear las semillas consume la pulpa y desperdicia el resto (el cual cae al suelo forestal); por ello se 


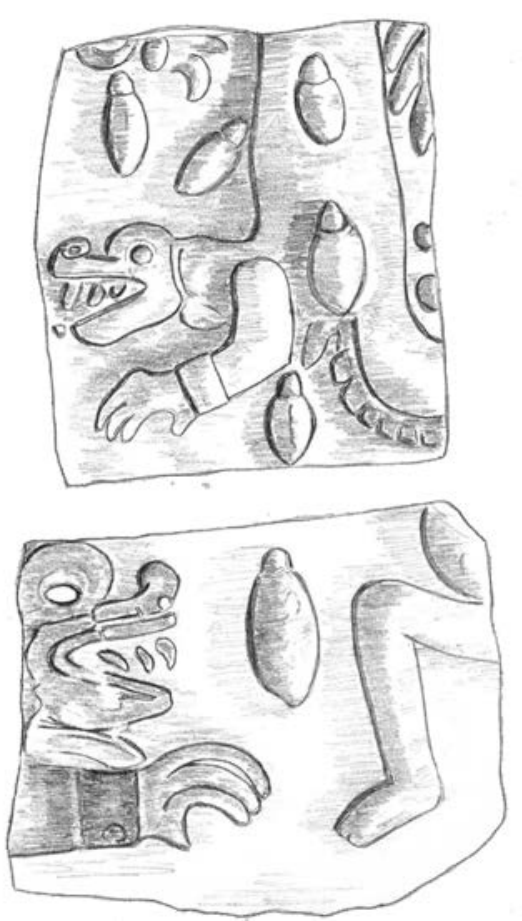

Figura 14. Fragmento procedente del Grupo El Osario, probablemente de la Casa de los Metates; originalmente pertenecía al Grupo de la Serie Inicial (Schmidt, 2007: figura 3)

le considera como un proveedor y dador del cacao, pues permite su ciclo natural. Desde esta perspectiva el pequeño primate se vincula con la fertilidad del cacao, pero a su vez es la gran amenaza para la cosecha porque roba el codiciado fruto. En el ámbito de lo simbólico, el mono estuvo además ligado a la glotonería, a la sexualidad y al placer en general; a su vez a la vida fácil, la danza, la música, las artes propias de la élite, conductas opuestas a la ruda vida del campesino (otra razón más para asociarlo con el cacao). Su propia sexualidad y su hábitat lo destinaron a un ámbito húmedo, bajo, exuberante, inframundano, como los espacios en donde se cultiva el cacao.

Las representaciones del binomio simio y cacao son muy tempranas, aún en Sudamérica. En una vasija de barro (estilo Tembladera procedente del valle Jequetepeque, al norte de Perú, 1000-700 a.C.), el animal se delinea sobre un árbol de cacao (figura 15). En diversas culturas mesoamericanas, como en el sureste de Veracruz, los monos figuran como animales afines al cacao; como ejemplo está la imagen de estilo Nopiloa del periodo Clásico, en la que se observa a un mono araña sedente y con grandes orejeras que al parecer ofrenda una mazorca de cacao (figura 16a), o bien se distingue a un simio en un árbol cargado de cacao procedente de la costa sur de Oaxaca (figura 16b). 
Entre los mayas del periodo Clásico el mono es representado como "dador" del cacao. Así se muestra en una figura de cerámica procedente del valle de Ulúa, Honduras (Henderson y Joyce, 2006: 142, figura 7.2), en la que se le bosquejó sedente y con adornos colgando de las orejas, portando en sus manos una mazorca de cacao (figura 17). O bien en un plato de barro resguardado en el Museo de San Francisco el simio aparece dando una gran zancada, con una mazorca en cada mano, un lazo a la cintura, otros en la muñecas y tobillos, y un listón todo manchado con el mismo color del cacao: su actitud revela júbilo por la acción que perpetúa (figura 18). Al representar los animales con adornos propios del ser humano, son alejados de la naturaleza e incorporados a un ámbito simbólico.

En otras ocasiones el mono se representa sin ningún atavío, más cercano a su naturaleza, como es el caso del vaso esgrafiado K4691 (Kerr, 1994: 593), donde figuran varios simios que no sólo ofrecen una mazorca de cacao, sino también la portan en sus espaldas; además varios pequeños elementos circulares caen de sus partes traseras a manera de excremento y parece que escupen las semillas (figura 19). En ocasiones comparten su preciado alimento con las ardillas, quienes también son entusiastas comensales del cacao, como en el vaso tallado K5185, ${ }^{24}$ donde uno de los monos lleva en la boca la mazorca (figura 20).

Tanto por su asociación con la fertilidad, así como por ser el gran depredador del cacao, quizá también lo llegaron a sacrificar para solicitar a las deidades el codiciado fruto. Así parece indicarlo la tapa de un incensario procedente de Toniná, en la que un mono tiene una cuerda al cuello de donde cuelgan mazorcas de cacao, usa un vistoso tocado con un rosetón adherido y grandes orejeras en forma de hojas, los ojos permanecen semicerrados y la lengua de fuera como si hubiera sido ahorcado (figura 21); ${ }^{25}$ de aquí se podría deducir que quizá lo sacrificaron estrangulándolo como tributo a alguna deidad del cacao.

Algunas imágenes que aparecen en varias vasijas (K5070, K1743, K345926) brindan nuevos datos, como aquéllas en las que los monos cargan una gran vaina de cacao y se acompañan con el glifo T539 (wa-ya), way o wahy; se ha discutido si este logograma corresponde a la tona o al nagual entre los nahuas, fenómenos que debieron tener muchos puntos cercanos y compartieron diversos elementos (Velásquez García, 2009: 612-615; Garza, 2012). No obstante, por ahora lo que estrictamente me interesa destacar es que el simio, designado en una de las vasijas (K5070) k'in to... batz', "sol mono aullador" (Grube y Nahm, 1994: 696), porta la vaina de cacao, imagen que reitera la pertenencia de este binomio al inframundo maya. Y, desde luego, el hecho de que en los tres ejemplos presenten el miembro viril visible, revalida su vínculo con la sexualidad propia de

\footnotetext{
${ }^{24}$ Denver Art Museum; Denver Colorado. Número del museo: 1989.214.

${ }^{25}$ Esta imagen es similar a las de cautivos entregados al sacrificio, como el silbato que encontró Chinchilla Mazariegos en Guatemala, donde se representa a un prisionero con las manos atadas a la espalda y un collar de vainas de cacao (Chinchilla Mazariegos, 2005: 17, fig. 16, apud McNeil, 2006: 15).

${ }^{26}$ Estas vasijas carecen de contexto arqueológico.
} 


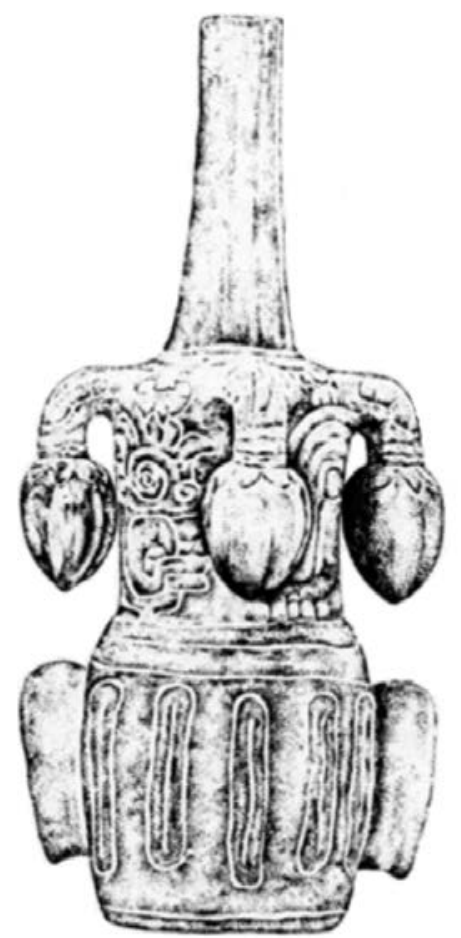

Figura 15. Vasija de barro estilo Tembladera, valle de Jequetepeque. Dibujo de Kata Fausta basado en una fotografía de Bonavía (Ogata, Gómez-Pompa y Taube, 2006: figura 3.9)
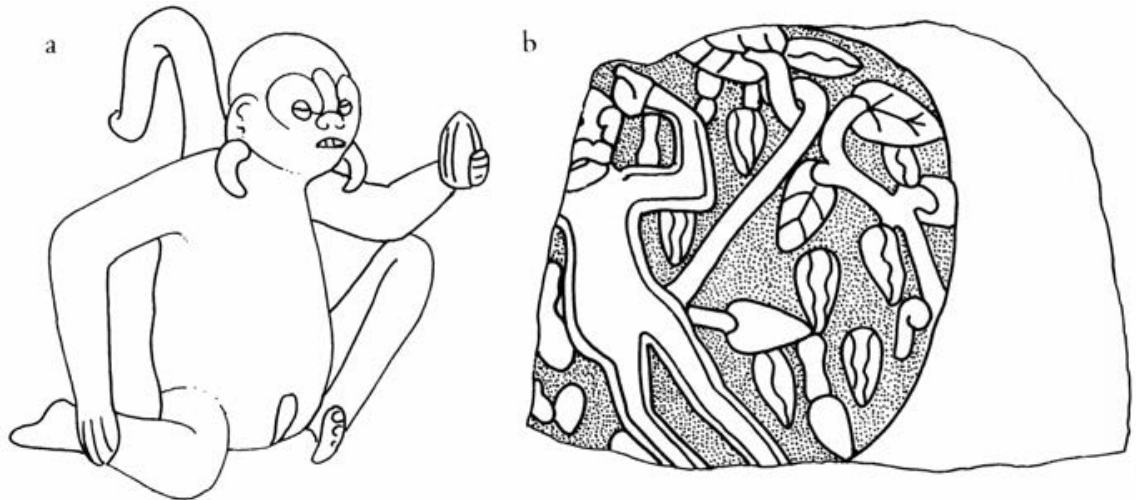

Figura 16. Imágenes del binomio mono-cacao en el periodo Clásico de Mesoamérica: a) Nopiloa, sur de Veracruz. Dibujado por Karl Taube basado en Easby y Scott (1970: 138), b) Mono en árbol de cacao, tiesto de Talun. Costa sur de Oaxaca. Dibujado por Karl Taube basado en Urcid (1993: figura 26-10) (Ogata, Gómez-Pompa, y Taube, 2006: figura 3.12) 


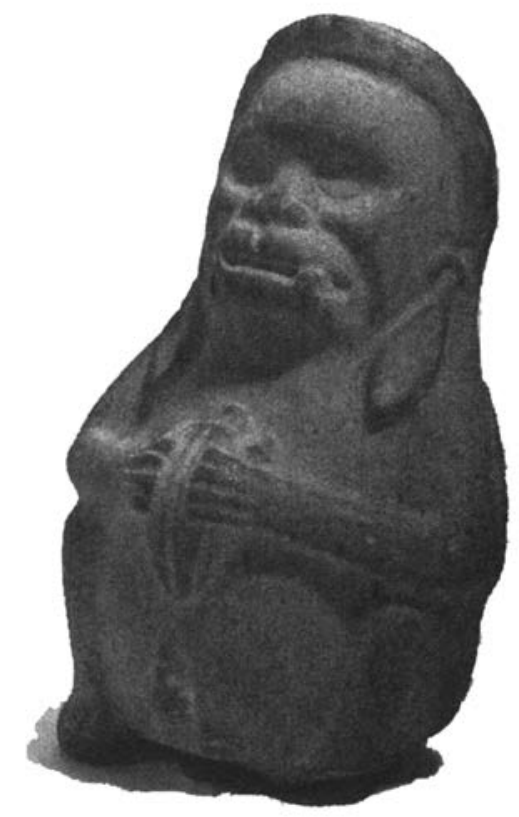

Figura 17. Cerámica en la que se representa un mono sosteniendo en sus manos una vaina de cacao (Henderson y Joyce, 2006: 142, figura 7.2). Peabody Museum, Harvard University, Photo 45-13-290/1568 N17851

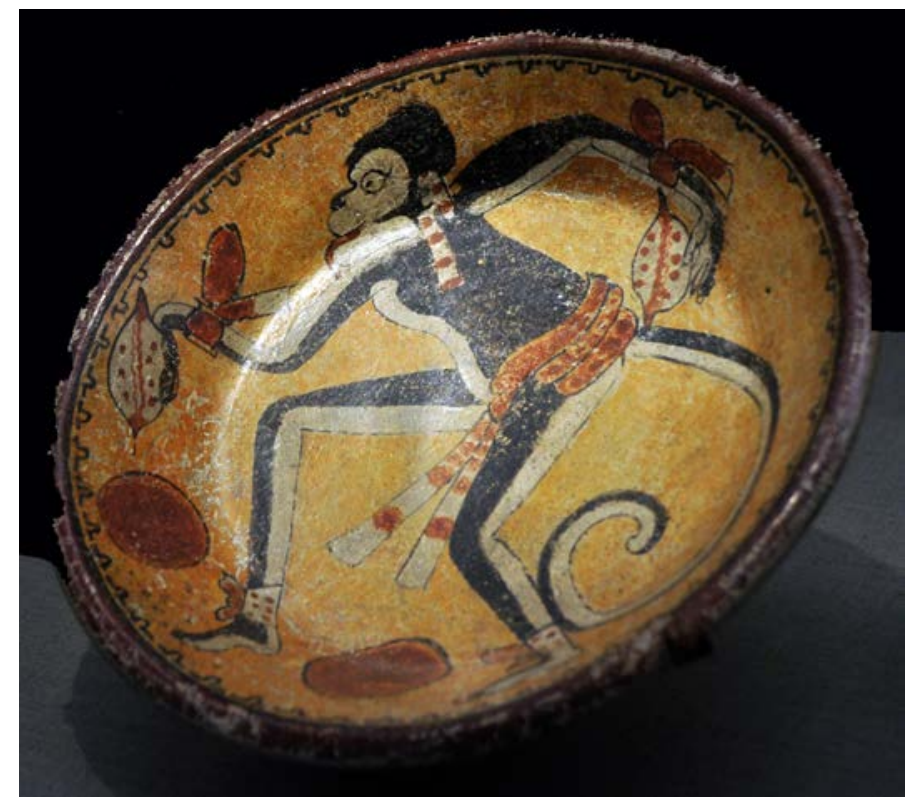

Figura 18. Plato de barro con un mono llevando una mazorca de cacao. 600-900 d.C. Donación de Gail y J. Alec Merriam al Museo de San Francisco L10.4.16. Fotografía de Rogelio Valencia 


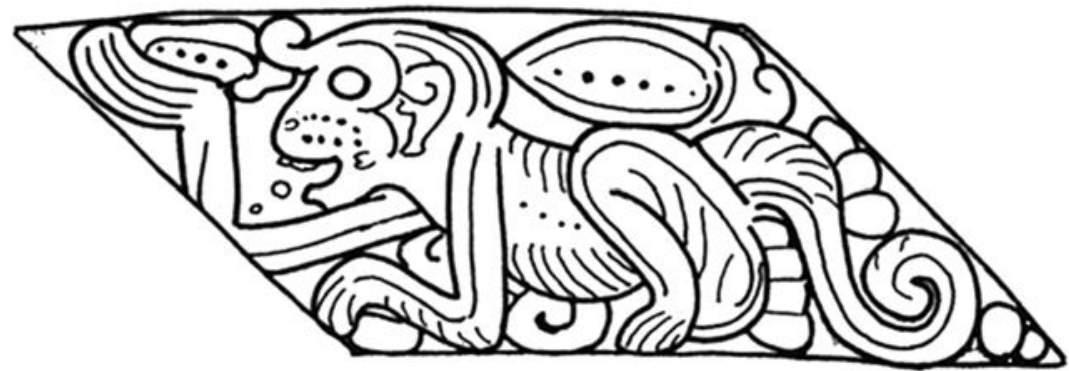

Figura 19. Fragmento del vaso K4691. Dibujo de Karl Taube basado en Kerr (1994: 593) en Ogata, Gómez-Pompa y Taube (2006: 85, fig. 3.10b)

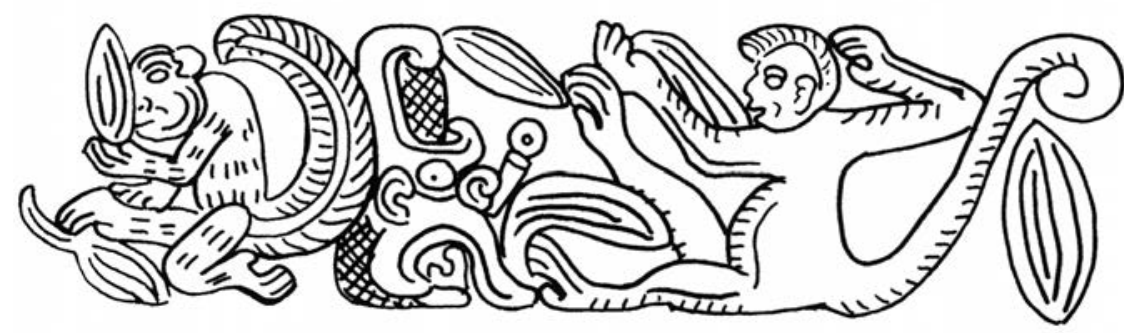

Figura 20. Fragmento de K5185. Detalle de una vasija. Dibujo de Karl Taube basado en Kerr (1997: 768) en Ogata, Gómez-Pompa y Taube (2006: 85 fig. 3.10d)

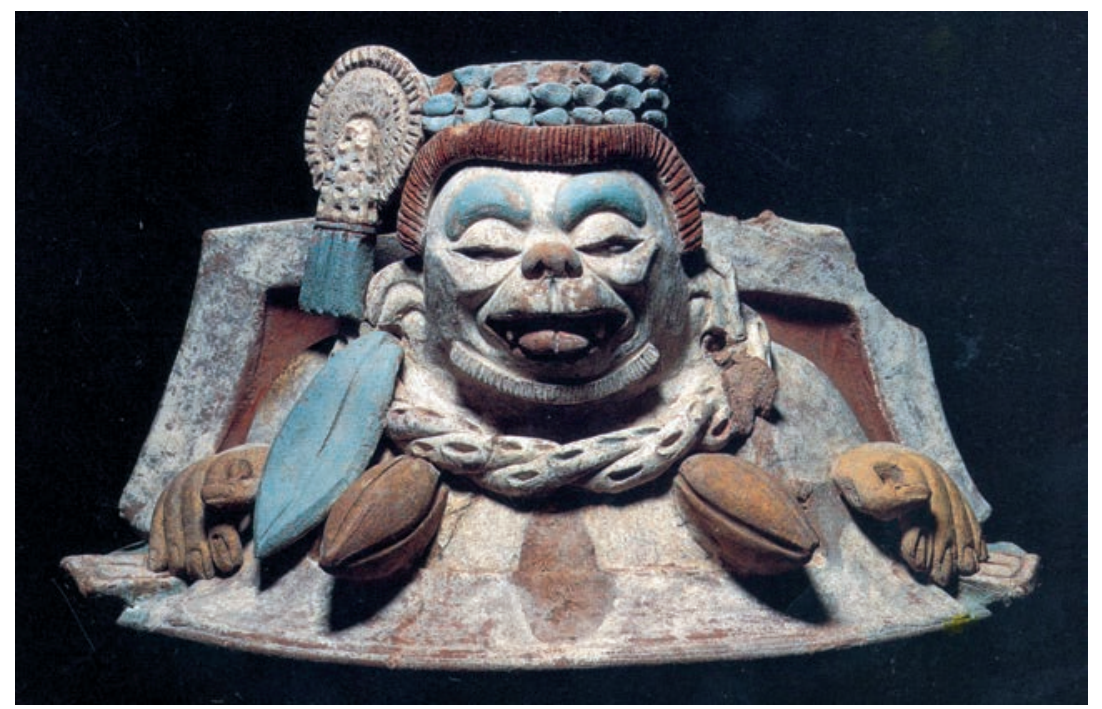

Figura 21. Imagen de un mono con una cuerda al cuello de la que penden vainas de cacao. Tapa de incensario de cerámica, Museo de Sitio de Toniná, INAH, Chiapas, 10-569388; 600-900 d.C. (Miller y Martin, 2004: lámina 40) 
este ámbito. Los simios de las vasijas mencionadas tienen oreja de jaguar y una orejera, pueden llevar un lienzo alrededor del cuello o de la cintura y uno de los ejemplos sostiene un gran cigarro en la boca; en las vasijas aparecen con otros animales que comparten el glifo T539, pero el mono es el único wahy que porta cacao (figura 22). Cabría preguntarse si el poseedor de este way o wahy fuera un hombre dedicado al comercio de este valioso fruto, lo cual sería su liga con el cacao. En el mismo orden de ideas cabría mencionar una vasija estilo Chamá (K1789), donde una hilera de monos sentados ofrece lo que parece ser una semilla de cacao; de su collar cuelga el motivo identificado como "ojos de la muerte" y a manera de pectoral se observan dos mazorcas de cacao, lo cual reitera su complejo simbólico (figura 23).

Siglos después y fuera del área maya, permanece el estrecho vínculo entre el cacao y el mono. Por ejemplo, en los murales del monasterio de Malinalco, estado de México, los frailes agustinos quisieron recrear un paraíso celeste en donde las almas van a gozar junto a Dios después de la muerte. El modelo de jardín pintado por los tlacuilos en el monasterio de la Purificación y San Simón

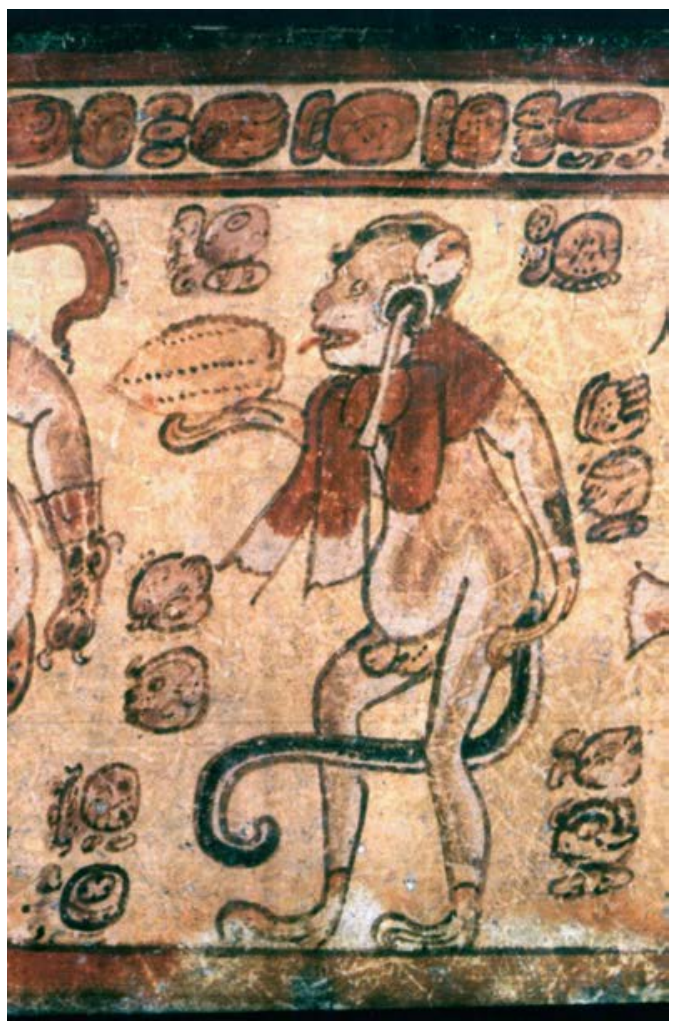

Figura 22. Vasija con mono wahy portando una mazorca de cacao (Kerr, 5070) 
incluyó a unos monos colgando del árbol del cacao (figura 24). Éste aparece como un espécimen central entre las plantas que constituían el jardín en el cielo indio-cristiano, lo cual refleja su estatus como un elemento sagrado en el mundo mesoamericano junto al mono que se deleitaba en su sabor adentro de este mundo armónico de indios y frailes viviendo en perfecta cristiandad, en un fragmento de la Jerusalén Indiana (Aguilar-Moreno, 2006: 273-288).

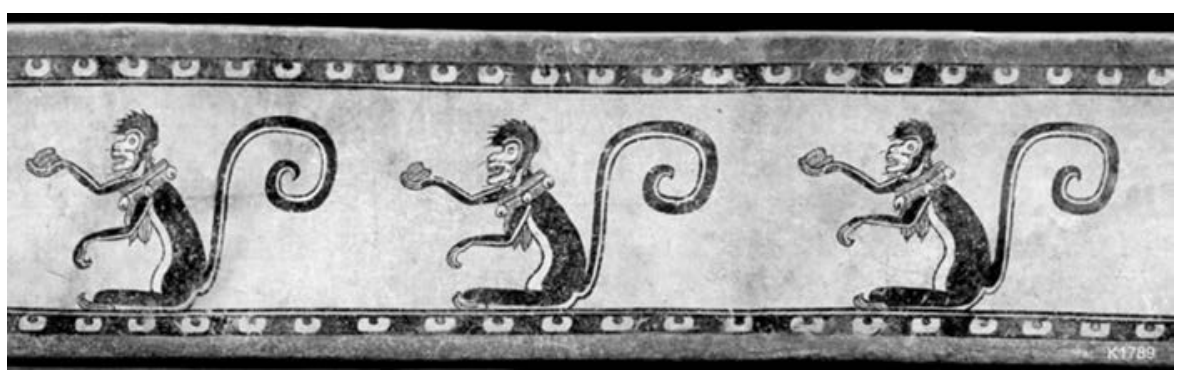

Figura 23. Vasija estilo Chamá (Kerr 1789)

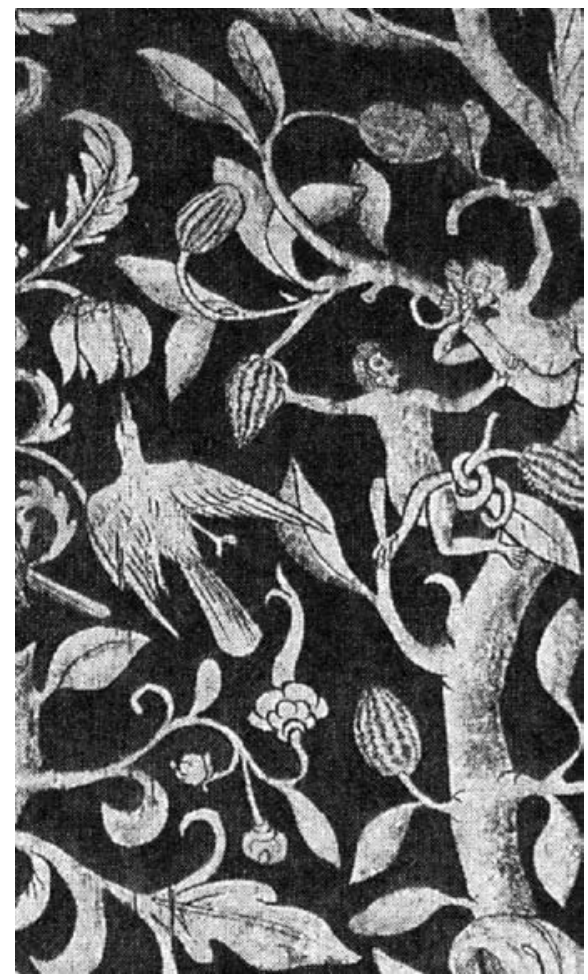

Figura 24. Fragmento del muro oriente del claustro bajo del monasterio agustino de la Purificación y San Simón, Malinalco (White Olascoaga y Zepeda Gómez, 2005: 74) 
Una vez corroborado el estrecho vínculo entre el mono y el cacao, tanto en el espacio simbólico como en la naturaleza, es posible retomar las imágenes del Grupo de la Serie Inicial, concretamente la Casa o Galería de los Monos (5C6) (figura 8) (Schmidt, 2007: 191-192, fig. 35 y 36; Schmidt, 2003, I: 23-26) en donde se distinguen en un friso dos tipos de representaciones. Este largo edificio se construyó al oeste de la plaza, región asociada con lo femenino y todas sus implicaciones simbólicas; mira hacia el este, pero tiene entrada también en el sur y quizá otra en el norte; en la moldura lleva filas de pequeñas esculturas de monos levantando la cola. En la parte superior del friso se labró a un personaje sedente sobre una banda celestial, tal vez un antepasado, con el nombre calendárico 10 Perro o Coyote; sostiene dos tallos gruesos y frondosos que terminan en cabezas serpentinas (figura 25a). En la franja inferior, hombres con cabeza de ave y enormes colgajos al cuello intentan perforar el vientre de monos en movimiento, quizá en actitud defensiva. Los simios están desnudos; no obstante, llevan un adorno sencillo con forma de caracol marino amarrado al cuello y orejeras. Los animales defecan o dejan caer elementos circulares: podría tratarse de semillas ingeridas con anterioridad. El hecho de que muestren algún tipo de atavío reitera su inserción en un mundo cultural.

A los hombres pájaro, tanto por el tamaño del pico como por la cresta, podemos identificarlos como carpinteros. ${ }^{27}$ En la espalda llevan alas labradas así como pequeños escudos; además, usan sandalias y adornos bajo las rodillas, por lo que es posible identificarlos como guerreros. Schmidt sugiere, remitiéndose a un mito rescatado por Anne Chapman entre los xicaque de Honduras (vecinos orientales de los mayas de Copán), que la imagen narra la transferencia de los alimentos a la humanidad por medio de unos animales. El relato indica que los micos son las estrellas que salen de noche:

En el cielo hay muchas montañas y muchos palos; robles, ocotes, encinos, cedros, matapalos... Toda la noche los micos están encajados en los palos comiendo frutas. Como comen frutas cagan semillas. La caca cae por acá como una brasa prendida y de ella nacen los robles, matapalos, encinos, ocotes, cedros bejucos, guamos de este mundo. No se pierde lo que cagan los micos; cagan semillas para que nazcan los palos de acá, para mantener los pájaros, como todo lo que tiene alas come frutas. De nosotros, de lo que cagamos no nace nada como comemos mucha comida cocida (Chapman, 1978: 163).

Comparto la idea de Schmidt de que las imágenes simbolizan una entrega de alimentos a los hombres, pero más que compararlo con un mito xicaque se podría equiparar con las historias sagradas de la tradición mesoamericana sobre el origen del maíz, y como ya se anotó esta planta y el cacao tuvieron fuertes vínculos simbólicos. Según se interpreta el texto colonial yucateco Libro de Chilam Balam

${ }^{27}$ Orden Piciforme, Subfamilia Picumninae; probablemente Dryocopus lineatus o campephilus guatemalensis. 


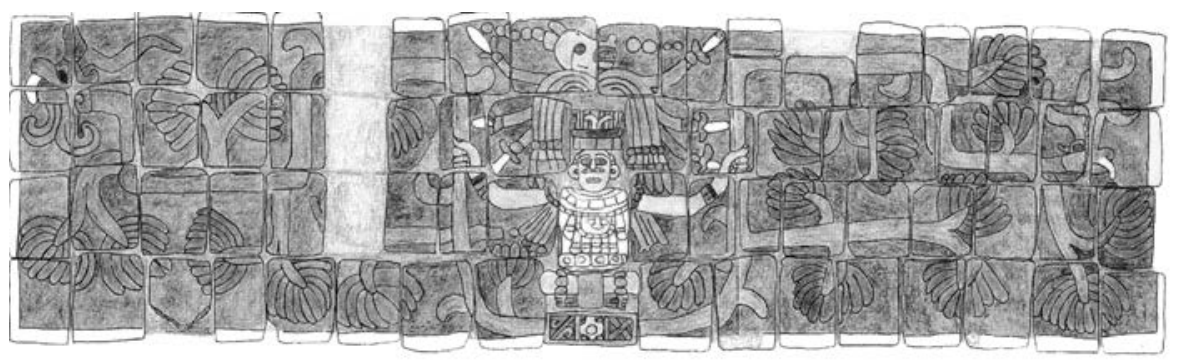

Figura 25a. Friso de la Casa de los monos (Schmidt, 2003, III: figura 50)

de Chumayel (1985: 99), la semilla se extrajo de una gran piedra gracias a la grieta producida por los rayos de la deidad Chac (Chaahk), el Gigante; pasaje similar al que se expresa en la mitología del centro de México, en la Leyenda de los soles (1992: 121). Allí se relata cómo a sugerencia de Quetzalcóatl, Nanáhuatl (quien se transfigurará en el Sol), golpea la montaña en donde se encontraba el maíz y ayudado por los rayos de los tlaloque logra hendir el Tonacatépetl y obtener el preciado grano para los hombres. En otros mitos mayas estos últimos descubren el maíz por conducto de algún animal que habita en Paxil. Por ejemplo, en los Anales de los Cakchiqueles (1980: 116) el maíz lo había ingerido el coyote, por ello fue descuartizado y entre sus despojos estaba el grano. En el Popol Vuh los guardianes del maíz en Paxil eran yaak, "gato del monte"; utiw "coyote"; k'el, "perico" o "chocoyo" (aratinga strenua), y joj, el "cuervo" (Popol Vuh, en prensa, párrafo 46). Si los mitos del maíz se convirtieron en un arquetipo del cual se derivaron otras historias sagradas, se puede inferir, de acuerdo con este patrón mítico, que el cacao debió estar resguardado en un sitio similar, en una Montaña de los Mantenimientos, tal vez dentro de algún animal.

En algunas comunidades contemporáneas (mopanes, pokomchi', mames, tzeltales, k'ekchi' y ch'oles) se reitera la mediación de un pájaro carpintero en la obtención del maíz. ${ }^{28}$ Los mames de San Ildelfonso Ixtahuacán relatan un mito en el que primero aparece un felino que consume "unas cositas amarillas"; cuando los hombres le preguntan sobre el sitio donde obtenía el grano, responde que lo había obtenido de una cueva en la montaña Paxil, el mismo sitio mencionado en el Popol Vuh y en los Anales de los cakchiqueles. El orificio para obtenerlo era demasiado pequeño, por ello le piden al pájaro carpintero que amplíe la abertura de la roca; sin embargo, su pico no fue del todo eficiente y sólo logra sacar unos granos de maíz que allí mismo comieron. Al fallar el ave, le solicitan ayuda al

\footnotetext{
${ }^{28}$ Thompson (1967) en un artículo titulado "Maya Creation Myths" relata que en 1930 recogió el mito entre los mopanes de San Antonio, Honduras, y agrega que los k'ekchi' también lo preservan, quienes a su vez tomaron la historia de los manché chol. En 1950 Thompson, en un trabajo de campo, la registró entre los mames de Colotenango. Diez años después logra lo mismo entre los pokomchi'.
} 
rayo, considerado un animal de fuego, y tras varios intentos logra abrir la roca (Navarrete Cáceres, 2002: 19-21); ${ }^{29}$ en los mitos k'iche' de San Andrés Xecul, el pájaro carpintero sí logra ensanchar la pequeña apertura en la roca y al gustarle el sabor del maíz se convierte en un dispersor del grano sobre los campos, y es la forma como los hombres obtienen las plantas de maíz (Rojas Lima, 1988: 83-84). En un mito similar de los tzeltales de Bachajón, Chiapas, se puntualiza que el rayo era el nahual del pájaro carpintero y era quien podía obtener el maíz (Slocum, 1965), por lo que ambas figuras se identifican.

En tanto, en un relato de los tzotziles de Zinacantan es precisamente un mono el que se encontraba en el interior de una cueva y era el poseedor del maíz; al descubrirlo unos cazadores, lo matan y le arrebatan las mazorcas para los hombres (García de León, 1973: 307-308). ${ }^{30}$

\section{La reconstrucción de un mito}

Contamos con una serie de elementos que es preciso unir y comparar para tratar de bosquejar una o varias historias sagradas, aunque la naturaleza fragmentaria de nuestras fuentes sólo permite una reconstrucción hipotética y provisional; no obstante, con estas advertencias en mente, podría intentar reorganizar algunos datos y esbozar inferencias viables acerca de la recuperación de un mito alrededor del cacao.

En principio habría que cuestionarse por qué siendo un alimento tan significativo, con la relevancia económica que tuvo durante siglos y por supuesto con implicaciones simbólicas y rituales aún vigentes en nuestros días, no sobrevivieron mitos de origen sobre el cacao (en contraste con las múltiples historias sagradas alrededor del maíz, de la forma en la que el hombre lo obtuvo y de cómo aprendió a prepararlo). Desde luego la razón fundamental es la relevancia que tuvo y conserva el maíz en la dieta mesoamericana; además, a diferencia de la gran difusión de historias sagradas sobre aquella semilla, los mitos del cacao debieron ser propios de la élite y tuvieron una menor difusión (al desaparecer los grupos de poder indígenas, se perdieron muchos de sus mitos). A esto se aúnan las controversias que el cacao suscitó durante la Colonia. En diferentes escritos europeos se discutieron sus virtudes o vicios; no obstante su grato sabor, el chocolate era ajeno a la vida austera y se consideró como una bebida afrodisiaca que promovía la pasión venérea. Además, con la pulpa se obtenía una bebida que al fermentarse embriagaba e intoxicaba (Henderson y Joyce, 2006: 140-153); por lo demás, se empleaba en múltiples rituales indígenas y se combinaba, como señala Garza, con alucinógenos, produciendo diversos estados de conciencia. Durante el siglo xvı las propiedades psicoactivas del chocolate lo convierten en una sus-

\footnotetext{
${ }^{29}$ Navarrete señala que el primero en publicar con algunas variantes el relato de San Ildelfonso Ixtahuacán fue Búcaro Moraga en 1959.

${ }^{30}$ El relato fue rescatado en 1970.
} 

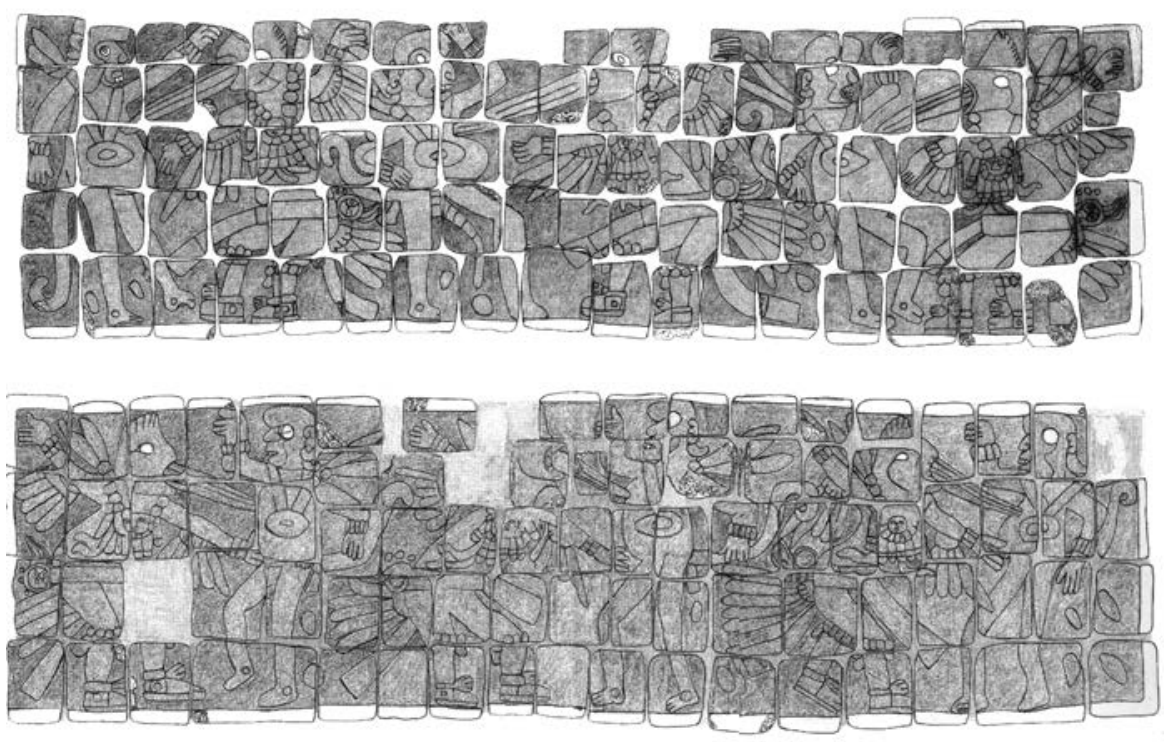

Figura 25b. Frisos de la Casa de los Monos (Schmidt, 2003; III: Figura 53)

tancia misteriosa o incluso relegada a la palabra del diablo; algunos miembros de la Iglesia lo declararon un alimento equivocado (Coe y Coe, 1999: 266-268). Todo ello debió ser un motivo para que se fueran perdiendo las historias sagradas sobre el cacao, aunque hoy día se conserve su uso en muchas ceremonias indígenas.

Por otro lado, las connotaciones simbólicas del simio durante la Colonia fueron peyorativas. El mono simboliza las bajas pasiones humanas y los pecados, se manifiesta como quien parodia las acciones humanas, representa a la lujuria del hombre en estado de degeneración. Es un animal incontinente que excreta mucho, defeca desde arriba, desperdicia comida, tira el alimento. Simboliza todo lo contrario a las conductas de templanza que buscaba inspirar el cristianismo.

Por ello propongo que sí existió un mito de origen sobre el cacao y que parte de su narrativa debió quedar impresa en algunas de las imágenes revisadas de Chichén Itzá, las cuales podrían constituirse en expresiones narrativas de una creencia mítica latente con una estructura compartida y común con el ciclo narrativo del maíz. Tenemos un elemento masculino, el rayo, el pájaro carpintero o el cazador, que al penetrar una montaña, una cueva o un vientre lo fertiliza simbólicamente para obtener un grano fecundado.

El Grupo de la Serie Inicial estuvo habitado durante varios siglos por un grupo poderoso, quizá comerciantes o cultivadores del cacao, que intentaban dar una visión paradisíaca de un lugar donde nunca faltaban los alimentos, como si se 
tratara de una gran bodega mítica. Allí abundaban los bienes, los mantenimientos, las aves y las flores, la fertilidad ligada a la sexualidad exuberante, y dentro de todo este imaginario destacaron de forma especial al cacao y a sus protectores. No en balde este grupo se ubica al sur de Chichén Itzá, rumbo sin lugar a dudas ligado con el inframundo en las creencias de los antiguos mayas.

A través de las imágenes descritas, como recordatorio de una antigua narrativa o cuadros de una historia sagrada, se podría inferir la existencia de un fondo mítico que responde asimismo a una narrativa espacial; ésta tendría lugar en los edificios alrededor de la plaza anexa a la Casa de los Búhos, ubicada hacia el sur del Grupo de la Serie Inicial al parecer coincidiendo en su distribución con la ubicación de los edificios.

La historia sagrada podría iniciarse con los relieves de una deidad celeste, quizá el Sol nocturno ubicado sobre una banda celeste (Casa de los Falos 5C14), quien en el tiempo de los orígenes se perfila como el dador de todos los alimentos; el personaje deja caer las mazorcas de cacao en medio de un gran bullicio que rompe el silencio de la creación, alboroto generado por otros individuos con máscara de ave y que tañen instrumentos musicales al mismo tiempo que danzan para festejar la llegada de tan preciado alimento y propiciar su reproducción (figuras 10a y 10b). Este cielo nocturno es una expresión simbólica del principio generador revelado también como el interior de la gran montaña de los mantenimientos. Este era un espacio repleto de abundancia en donde proliferaban las flores, el cacao y las piedras preciosas, protegido por un personaje que renacía de una gran semilla-bodega, la montaña que se hiende, en donde se guardaban todos los mantenimientos (figura 11) (Casa de los Falos superior y Casa de los Caracoles 5C5). En este ámbito no podían faltar los grandes árboles de cacao del tiempo de los orígenes, que se erguían cargados con sus mazorcas y a su vez sostenían el cosmos (Casa de los Búhos 5C7) (figura 13).

Es de estos árboles que K’awiil (Tapa de Bóveda de la Casa de los Búhos 5C7) obtiene grandes riquezas, entre ellas el preciado cacao, bien procedente de un espacio inframundano repleto de fertilidad y transportado por aquel a la superficie terrestre como regalo a una antigua humanidad (figura 12). ${ }^{31}$

El mono, animal que tiene como alimento predilecto al cacao, lo roba de un árbol cuyo tronco forma la cabeza de un saurio, como se sugiere en el fragmento encontrado en El Osario (figura 14). ${ }^{32}$ Su verdadero poseedor habitaba en una cueva saturada de riquezas, presidida por un posible antepasado de los itzáes,

31 José Alejos y Michela Craveri (comunicación personal) consideran que serían dos patrones narrativos diferentes; en uno K'awiil, actuando como un elemento fecundador masculino, el rayo, rompe la tierra y lleva a la tierra el cacao; la segunda narración estaría en el resto de las imágenes. Esta interpretación también es factible; no obstante, la reconstrucción del mito, reitero, es sólo una propuesta y por ello acepto la posibilidad de varias historias sagradas.

${ }^{32}$ Recuérdese que, según Schmidt, este fragmento también proviene del Grupo de la Serie Inicial. 
10 Perro o Coyote ${ }^{33}$ (figura 25a). En ese ámbito (Casa o Galería de los Monos 5C6) localizado en el occidente de la plaza moraban también los Pawahtunes, quienes se autosacrificaban y danzaban por la fecundidad del grano (figura 9). El simio ingirió el cacao y a través de sus desperdicios se dieron a conocer las semillas ya fertilizadas, mostrándose además como un intermediario entre el mundo divino y el humano; por ello se envió al pájaro carpintero a que abriera el vientre del mono para obtener el grano, ave que actuó como el rayo en los mitos del maíz o bien como un elemento masculino fecundador; el responsable de esta acción mítica parece ser 10 Perro o Coyote. En esta aleatoria secuencia narrativa se reafirma el mismo modelo mítico del maíz antes comentado.

Desde luego es sólo un intento de encontrar sentido a un grupo de representaciones, una propuesta de un mito o quizá varios mitos que pudieron existir en un pasado remoto, que fueron distorsionados en la memoria con el tiempo; interpretación a la que llegué comparando las imágenes con mitos que tienen una estructura semejante para intentar acercarme un poco al pensamiento sagrado maya.

33 Tanto el perro como el coyote estaban también ligados con lo nocturno, con el inframundo y, por ende, con la fertilidad. 


\section{BIBLIOGRAFÍA}

Aguilar-Moreno, Manuel

2006 "The Good and Evil of Chocolate in Colonial Mexico", Chocolate in Mesoamerica. A Cultural History of Cacao, Cameron McNeil (ed.). Gainesville: University Press of Florida, 273-288.

Anales de Cuauhtitlán

1992 Códice Chimalpopoca, Primo Feliciano Velázquez (trad.). México: Universidad Nacional Autónoma de México, Instituto de Investigaciones Históricas (Primera Serie Prehispánica, 1).

Anales de los Cakchiqueles

1980 Adrián Recinos (trad., introd. y n.), Literatura Maya, Mercedes de la Garza (comp. y prol.). Barcelona: Biblioteca Ayacucho.

Andalón González, Mónica Guadalupe

2010 "El cacao en Mesoamérica: aspectos naturales y culturales", tesis para obtener el grado de Maestría en Estudios Mesoamericanos. México: Universidad Nacional Autónoma de México.

Caso Barrera, Laura y Mario Aliphat F.

2008 "Los vasos como símbolo de poder entre los itzáes”, Símbolos de poder en Mesoamérica, Guillhem Olivier (coord.). México: Universidad Nacional Autónoma de México.

Chapman, Anne

1978 Les enfants de la mort: univers mythique des indiens tolupan (Jicaque). México: Mission Archeologique et Ethnologique Française au Mexique, 1978 (Etudes Mesoamericaines).

Chinchilla Mazariegos, Oswaldo

2005 "Yuk'ib tayutal Kakaw", Kakaw. El chocolate en la cultura de Guatemala, Oswaldo Chinchila Mazariegos (ed.). Guatemala: Museo del Popol Vuh.

Chuchiak, John F.

2000 "The Indian Inquisition and the Extirpation of Idolatry: The Process of Punishment in the Provisorato de Indios of the Diocese of Yucatán, 1563-1812", tesis para detener el grado de Philosophy Doctor. Nueva Orleans: Tulane University.

Coe, Sophie D. y Michael D. Coe

1999 La verdadera historia del chocolate. México: Fondo de Cultura Económica.

Craveri, Michela

2011 Popol Vuh. Herramientas para una lectura crítica del texto k’iche. México: Universidad Nacional Autónoma de México, Instituto de investigaciones Filológicas. 
Díaz del Castillo, Bernal

$1991 \quad$ Historia verdadera de la conquista de la Nueva España. México: Alianza Editorial.

Diccionario maya Cordemex

1980 Alfredo Barrera Vásquez et al. (ed.). Mérida: Cordemex, 1980.

Dreiss, Meredith L. y Sharon Edgar Greenhill

2008 Chocolate. Pathway to the Gods. The Sacred Realm of Chocolate in Mesoamerica. Tucson: The University of Arizona Press.

Durán, Diego

1967 Historia de las Indias de Nueva España e Islas de la Tierra Firme, Ángel Ma. Garibay K. (ed.), 2 vol. México: Porrúa (Biblioteca Porrúa, 36 y 37).

Easby, Elizabeth K. y John F. Scott

1970 Before Cortés: Sculpture of Middle America. Nueva York: The Metropolitan Museum of Art.

Faust, Betty B.

1998 "Cacao Beans and Chili Peppers: Gender Socialization in the Cosmology of a Yucatec Maya Curing Ceremony”, Sex Roles, 39 (7-8): 603-642.

Fuentes y Guzmán, Francisco Antonio de

1932 Recordación Florida. Discurso historial y demostración natural, material, militar y política del Reyno de Guatemala, tomos I-III Guatemala: Tipografía Nacional (Biblioteca Goathemala de la Sociedad de Geografía e Historia, volumen $\mathrm{V})$.

García de León, Antonio

1973 "Breves notas sobre la lengua tzotzil: literatura oral y clasificadores numerales”, Estudios de Cultura Maya, IX: 303-312. México: Universidad Nacional Autónoma de México, Centro de Estudios Mayas.

Garza, Mercedes de la

2012 Sueño y éxtasis. Visión chamánica de los nahuas y los mayas. México: Universidad Nacional Autónoma de México, Instituto de Investigaciones Filológicas / Fondo de Cultura Económica.

Grube, Nikolai y Werner Nahm

1994 "A census of Xibalba: A complete inventory of way characters on Maya ceramics", Justin Kerr, The Maya vase book: A corpus of rollout photographs of Maya vases, vol. 4. Nueva York: Kerr Associates, 686-715.

Grube, Nikolai y Maria Gaida

2006 Die Maya Schrift un Kunst. Berlín: Etnologisches Museum Staatlichen Museen zu Berlin. 
Henderson, John S. y Rosemary A. Joyce

2006 "Brewing Distinction: The Development of Cacao Beverages in Formative Mesoamerica”, Chocolate in Mesoamerica. A Cultural History of Cacao. Cameron McNeil (ed.). Gainesville: University Press of Florida / Peabody Museum.

Kerr, Justin

1994

The Maya Vase Book: a Corpus of Rollout Photographs of Maya Vases, vol. 4. Nueva York: Kerr Associates.

Kufer, Johanna y Michael Heinrich

2006 "Food for the Rain Gods: Cacao in Ch'orti' ritual", Chocolate in Mesoamerica: A Cultural History of Cacao, C. L. McNeil (ed.). Gainesville: University of Florida Press, 384-407.

Landa, fray Diego de

1994 Relación de las cosas de Yucatán, María del Carmen León Cázares (est. prel., cronol. y rev. del texto). México: Consejo Nacional para la Cultura y las Artes (Cien de México).

Leyenda de los soles en Códice Chimalpopoca

1992 Códice Chimalpopoca, Primo Feliciano Velázques (trad.). México: Universidad Nacional Autónoma de México, Instituto de Investigaciones Históricas (Primera Serie Prehispánica, 1).

Libro de Chilam Balam de Chumayel

1985 Antonio Mediz Bolio (trad. del maya al castellano), Mercedes de la Garza (pról., introd. y n.). México: Secretaría de Educación Pública (Cien de México).

López Austin, Alfredo

1994 Tamoanchan y Tlalocan. México: Fondo de Cultura Económica.

Martin, Simon

2006 "Cacao in Ancient Maya Religion: First Fruit from the Maize Tree and other Tales from the Underworld", Cameron Mc Neil (ed.), Chocolate in Mesoamerica. A Cultural History of Cacao. Gainesville: University Press of Florida, 154183.

McNeil, Cameron (ed.)

2006a Chocolate in Mesoamerica. A Cultural History of Cacao. Gainesville: University Press of Florida.

McNeil, Cameron

2006b "Introduction: The Biology, Antiquity, and Modern Uses of the Chocolate Tree (Teobroma cacao L.)", Cameron McNeil (ed.), Chocolate in Mesoamerica. A Cultural History of Cacao. Gainesville: University Press of Florida, 1-30.

McNeil, Cameron L., W. Jeffrey Hurst y Robert J. Sharer

2006 "The Use and Representation of Cacao During the Classic Period at Copan, 
Honduras", Chocolate in Mesoamerica: A Cultural History of Cacao, C. L. McNeil (ed.). Gainesville: University of Florida Press, 224-252.

Miller, Mary Ellen y Karl Taube

2004 Courtly Art of the Ancient Maya. Londres y Nueva York: Thames and Hudson.

Navarrete Cáceres, Carlos

2002 Relatos mayas de tierras altas sobre el origen del maíz: los caminos de Paxil. México: Universidad Nacional Autónoma de México, Instituto de Investigaciones Antropológicas (Colección Textos. Serie Antropología e Historia Antigua).

Ogata, Nisao, Arturo Gómez-Pompa y Karl A. Taube

2006 "The Domestication and Distribution of Theobroma cacao L. in the Neotropics", Chocolate in Mesoamerica: A Cultural History of Cacao, C. L. McNeil (ed.). Gainesville: University of Florida Press, 69-89.

Popol Vuh. Herramientas para una lectura crítica del texto k'iche'

En Traducción y análisis crítico por Michela Craveri. México: Universidad Naprensa cional Autónoma de México, Instituto de investigaciones Filológicas.

Pérez Ruiz, Francisco, José Osorio León, María Rocío González de la Mata

2009 "Reflexiones sobre los Pauahtunes de Chichén-Itzá", Los Investigadores de la Cultura Maya 18, tomo II. Campeche: Universidad Autónoma de Campeche, 269-294.

Reents-Budet, Dorie

2006 "The Social Context of Kakaw. Drinking among the Ancient Maya”, Cameron McNeil (ed.), Chocolate in Mesoamerica. A Cultural History of Cacao. Gainesville: University Press of Florida, 202-223.

Rojas Lima, Flavio

1988 La cultura del maíz en Guatemala. Guatemala: Ministerio de Cultura y Deportes (Colección Ixim).

Sahagún, Bernardino de

1989 Historia general de las cosas de Nueva España, 2 vol. Primera versión íntegra del texto castellano del manuscrito conocido como Códice Florentino, Alfredo López Austin y Josefina García Quintana (introd., pal., glos. y n.). México: Consejo Nacional para la Cultura y las Artes / Alianza.

Schmidt, Peter J.

1999 “Chichén Itzá. Resultados y proyectos nuevos (1992-1999)", Arqueología Mexicana, VII (37): 32-39. México: Raíces/Instituto Nacional de Antropología e Historia.

2003 "Proyecto Chichén Itzá: Informe de actividades, julio de 1999 a diciembre de 2002", Centro InAH, Yucatán, México (manuscrito, 3 volúmenes).

2004 "Chichén Itzá”, Arqueología Mexicana, II (10): 20-25. México: Raíces / Instituto Nacional de Antropología e Historia. 
Schmidt, Peter J.

2005 "Nuevos hallazgos en Chichén Itzá”, Arqueología Mexicana, XIII (76): 48-55.

2007 "Bird, ceramics, and cacao: new excavations at Chichén Itzá, Yucatan”, en Twin Tollans. Chichén Itzá, Tula, and the Epiclassic to Early Postclassic Mesoamerican World, Jeff Karl Kowalski y Cynthia Kristan-Graham (eds.). Washington: Dumbarton Oaks Research Library and Collections, 151-203.

Slocum, Mariana

1965 "The Origin of Corn and Other Tzeltal Myths", Tlalocan. Revista de fuentes para el conocimiento de las culturas indígenas de México, V (1): 1-45. México: Universidad Nacional Autónoma de México.

Thompson, J. Eric

1967 “Maya Creation Myths [Part 2]”, Estudios de Cultura Maya, VI: 15-43. México: Universidad Nacional Autónoma de México.

Urcid, Javier

1993 "The Pacific Coast of Oaxaca and Guerrero: The Westernmost Extent of Zapotec Script”, Ancient Mesoamerica, 4 (1): 141-165.

Valencia, Rogelio

2010 "La abundancia y el poder real: el dios K’awiil en el Posclásico”, III Simposio Internacional de Hispanistas "Encuentros 2010". Polonia: Universidad de Varsovia.

Velásquez García, Erik

2009 "Los vasos de la entidad política de 'Ik': una aproximación histórico-artística. Estudio sobre las entidades anímicas y el lenguaje gestual y corporal en el arte maya Clásico", tesis para obtener el grado de doctor en Historia del Arte. México: Universidad Nacional Autónoma de México.

Villacorta Calderón, José Antonio y Carlos Villacorta

1976 Códices mayas: reproducidos y desarrollados. Guatemala: Tipografía Nacional.

White Olascoaga, Laura y Carmen Zepeda Gómez

2005 El paraíso botánico del convento de Malinalco, Estado de México. México: Universidad Autónoma del Estado de México (Colección Luis Mario Schneider). 